\title{
Mud-Dominated Basin-Margin Progradation: Processes and Implications
}

DOI:

10.2110/jsr.2016.61

\section{Document Version}

Accepted author manuscript

Link to publication record in Manchester Research Explorer

\section{Citation for published version (APA):}

Poyatos-More, M., Jones, G. D., Brunt, R., David M. Hodgson, Richard J. Wild, \& Flint, S. (2016). Mud-Dominated Basin-Margin Progradation: Processes and Implications. Journal of Sedimentary Research, 86(8), 863-878. https://doi.org/10.2110/jsr.2016.61

\section{Published in:}

Journal of Sedimentary Research

\section{Citing this paper}

Please note that where the full-text provided on Manchester Research Explorer is the Author Accepted Manuscript or Proof version this may differ from the final Published version. If citing, it is advised that you check and use the publisher's definitive version.

\section{General rights}

Copyright and moral rights for the publications made accessible in the Research Explorer are retained by the authors and/or other copyright owners and it is a condition of accessing publications that users recognise and abide by the legal requirements associated with these rights.

\section{Takedown policy}

If you believe that this document breaches copyright please refer to the University of Manchester's Takedown Procedures [http://man.ac.uk/04Y6Bo] or contact uml.scholarlycommunications@manchester.ac.uk providing relevant details, so we can investigate your claim.

\section{OPEN ACCESS}


3 Miquel Poyatos-Moré ${ }^{1 *}$, George D. Jones ${ }^{2}$, Rufus L. Brunt ${ }^{1}$, David M. Hodgson ${ }^{3}$, Richard J. Wild ${ }^{4}$ and

Stephen S. Flint ${ }^{1}$

${ }^{1}$ Stratigraphy Group, School of Earth, Atmospheric and Environmental Sciences, University of Manchester, Manchester M13 9PL, UK

${ }^{2}$ VNG Norge, Filipstad Brygge 1, 0252 Oslo, Norway

${ }^{3}$ Stratigraphy Group, School of Earth and Environment, University of Leeds, Leeds LS2 9JT, UK

${ }^{4}$ Statoil ASA, Exploration Research, Arkitekt Ebbells veg. 10, Rotvoll, Norway *email: miquel.poyatos-more@manchester.ac.uk

ABSTRACT: The accretion of coarse-grained material at the shelf-edge rollover has been emphasized in studies of basin margin progradation, despite fine grained sediment (clay and silt) representing a volumetrically more significant component of subaqueous clinothems. The timing and processes of fine-grained sediment transport across the shelf and onto the slope remains an understudied facet of sedimentary basin stratigraphy. Three exhumed basin margin-scale clinothems of the Permian Waterford Formation, in the Karoo Basin, South Africa, offer outcrop examples of margin development through the accretion of mud during flooded shelf conditions. The progradation of wave/storm-influenced sandy shelf topset deposits over a thick mudstone succession and beyond a previously established sand-rich shelf-edge rollover suggests that some periods of basin margin progradation took place exclusively via dilute mud-rich gravity flows. Detailed outcrop and core study of offshore mudstones reveals a high content of organic debris and mica. Individual beds show normal and inverse grading, internal erosion surfaces and moderate to low bioturbation, reflecting relatively stressed conditions in frequently supplied outer shelf to upper slope regions. The estimated low gradient $\left(<0.7^{\circ}\right)$ of the Karoo Basin margin and prevailing wave/storm conditions facilitated prolonged suspension of fluid mud and transport across the shelf and beyond the shelf-edge rollover in sediment gravity flows. This study represents a rare example of mudstone-dominated shelf-edge rollover deposits documented at outcrop and core, and demonstrates how fine-grained sediment accretion can play a significant role in basin margin progradation. Conventional depositional models 
31 do not adequately account for progradation of basin margins in the absence of sand supply, which implies potential risks in the identification of shelf edge rollover positions and application of trajectory analysis in strongly progradational margins.

\section{INTRODUCTION}

Mud-rich clinothems are major components of continental shelves and the progradation of muddominated deltas has been widely described in modern systems (e.g. Cattaneo et al. 2007; Slingerland et al. 2008). Shelf-edge progradation is commonly associated with the accretion of coarse-grained material (very fine sand and coarser) on and beyond the rollover (zone between the topset and foreset), when sedimentation in topsets is limited by low accommodation and/or high sediment supply (Morton and Suter 1996; Muto and Steel 2002; Steel and Olsen 2002; Steel et al. 2003; Johannessen and Steel 2005; Porębski and Steel 2006; Carvajal and Steel 2009; Carvajal et al. 2009; Covault et al. 2009; Olariu and Steel 2009; Hubbard et al. 2010; Dixon et al. 2012a; 2012b). Typically, the recognition of sand-rich shelf-edge rollovers is used in outcrop and subsurface studies to define basin margin clinothems (e.g. Plink-Björklund and Steel 2002; Mellere et al. 2003; Pyles and Slatt 2007; Uroza and Steel 2008; Dixon et al. 2012a) (Fig. 1). The trajectory of multiple shelf-edge rollovers can be used to infer long-term relative sea-level changes (e.g. Steel and Olsen 2002; Helland-Hansen and Hampson 2009; Henriksen et al. 2009; 2011; Olariu et al. 2012). When trajectory is used in combination with the interpreted dominant shelf-edge process regime (Dixon et al. 2012b), the timing of coarse-grained sediment delivery from shelves to deep basins can be predicted. Mud-grade sediment is a volumetrically significant proportion of the total sediment transferred by rivers (e.g. Burgess and Hovius 1998), and a major sediment component in modern shelf construction (McCave 1972; Nittrouer et al. 1986; Kineke et al. 1996; Kuehl et al. 1996; Kuehl et al. 1997; Michels et al. 1998; Kineke et al. 2000; Liu et al. 2001; Bentley 2003; Hill et al. 2009). Consequently subaqueous deltas, shelf-edge rollovers, and basin margin clinothems are dominated by thick mud(stone)-rich packages (e.g. Damuth et al. 1988; Bohacs 1998; Driscoll and Karner 1999; Cattaneo et al. 2007; Liu et al. 2007; Slingerland et al. 2008; Bohacs et al. 2014; Patruno et al. 2015) (Fig. 1), despite the emphasis commonly being on their sand-rich components. In addition, oceanographic studies have documented the existence of high energy prograding mud-rich shelves (Rine and 

2003; Rotondo and Bentley 2003; Walsh et al. 2004; Ta et al. 2005).

62 A re-examination of mud transport processes (Macquaker and Bohacs 2007; McAnally et al. 2007; Schieber et al. 2007; Schieber and Southard 2009; Schieber and Yawar 2009) and the mechanisms responsible for widespread distribution of mud along the shelf (Nemec 1995; Abbott 2000; Traykovski et al. 2000; Parsons et al. 2001; Dalrymple and Cummings 2005; Pattison 2005; Nakajima 2006; Macquaker et al. 2007; Varban and Plint 2008; Ichaso and Dalrymple 2009; Macquaker et al. 2010; Ghadeer and Macquaker 2011; Harazim and Mcllroy 2015) have led to a major reappraisal of finegrained successions in ancient shelves and epicontinental seas (e.g. Soyinka and Slatt 2008; Bhattacharya and MacEachern 2009; Plint et al. 2009; MacKay and Dalrymple 2011; Plint et al. 2012; 2014; Wilson and Schieber 2014). However, there remains a lack of detailed studies across ancient mudstone-rich shelf-edge rollover successions (type 4 clinothems of Steel et al. 2000), and the mechanism and timing for basin margin clinothem progradation under mud-dominated supply regimes are still poorly constrained.

This study of the Permian Waterford Formation, Karoo Basin (South Africa), utilizes an established stratigraphic framework (Wild et al. 2009; Jones et al. 2013; 2015), but focuses specifically on documenting a particular style of mudstone-dominated basin margin progradation in two basin margin-scale clinothems. The combined outcrop and core dataset permits to i) recognize and provide a depositional model of the shelf-to-slope transition in fine grained successions; ii) to understand the processes responsible for the transport and deposition of outer shelf and upper slope mudstones; and iii) to consider and discuss the implications of basin margin growth in the absence of coarse-grained sediment delivery at the shelf edge.

82

84 The 5500-m-thick Karoo Supergroup in the SW Karoo Basin of South Africa comprises the Dwyka 85 Group (Late Carboniferous to Early Permian glacial deposits), the Ecca Group (Permian clastic 86 marine/marginal marine) and the Beaufort Group (Permo-Triassic fluvial sediments) (Veevers et al. 1994; Johnson et al. 1997; Visser 1997; Rubidge et al. 2000; Cole and Whipplinger 2001) (Fig. 2).

88 Subsidence during Ecca Group time was generated by a combination of dynamic topography related to subduction of the paleo-Pacific oceanic plate, and inherited basement structures (Visser and 
Praekelt 1996; Pysklywec and Mitrovica 1999; Tankard et al. 2009), that led to the development of the Tanqua and Laingsburg depocenters.

92 The Karoo Basin deep water succession (Wickens 1994; Hodgson et al. 2006; Flint et al. 2011) is overlain by upper slope and shelf deposits of the Waterford Formation (Wickens 1994) (Fig. 2), a 400 m-thick mixed-influence deltaic succession (Wild et al. 2009; Oliveira et al. 2011; Jones et al. 2013). The complete vertical stratigraphic transition from slope channel-levee systems (Wild et al. 2005; Hodgson et al. 2011) to shelf deltas, in combination with extensive down-dip exposures, permits the geometry of the basin margin to be reconstructed, and the identification of successive basin margin clinothems and their shelf-edge rollover positions (Wild et al. 2009; Oliveira et al. 2011; Dixon et al. 2012a; Jones et al. 2013; 2015). Recent improved constraints on the timing of sedimentation from U$\mathrm{Pb}$ volcanic ash dating (Fildani et al. 2007; Fildani et al. 2009; McKay et al. 2015) suggest deltaic deposition began slightly earlier in the Tanqua than in the Laingsburg depocenter. However, the correlation of time-equivalent units between both depocenters is not the objective of this paper.

103 The dataset in the $6000 \mathrm{~km}^{2}$ study area (Fig. 2) includes 66 detailed logged sections (15 in Tanqua,

10451 in Laingsburg) and a $550 \mathrm{~m}$ fully cored research borehole (SL1), that collectively total nearly $21 \mathrm{~km}$ of measured thickness, with units walked out between logs to provide physical stratigraphic correlation. The outcrop dataset from both depocenters is displayed in $>40 \mathrm{~km}$-long correlation panels (Figs. 3, 4). Collection of unidirectional paleoflow measurements from ripple foresets and flute casts, and bidirectional measurements from groove marks and the crest-lines of symmetrical ripples indicate that the overall paleoflow was to the NE and $E\left(030^{\circ}-080^{\circ}\right)$ such that the panels are sub-parallel to depositional dip, with landward to the west and south and basinward to the east and north. Panels in Laingsburg are about $6 \mathrm{~km}$ apart across depositional strike, providing three-dimensional control on sedimentological characteristics and depositional architecture for each clinothem (Jones et al. 2015).

\section{FACIES ANALYSIS}

115 The sedimentary facies scheme is largely based on previous studies (Wild et al. 2009; Oliveira et al. 116 2011; Jones et al. 2013) and is presented in Table 1. The sand-dominated facies associations of the 117 Waterford Formation topset deposits exhibit characteristics that are consistent with mixed wave- and 118 river-influenced shoreline settings (Reineck and Singh 1973; Harms et al. 1975; 1982; McCubbin 1982; Browning et al. 2006; Ainsworth et al. 2011). This work focusses on the range of facies and 
120 facies associations that span from outer shelf through shelf-edge rollover to upper slope depositional

121 settings (Table 1). Overall, the amount of Sedimentary structures that indicate river-dominance is less 122 in Laingsburg than in Tanqua, and therefore shoreface nomenclature is used to interpreted the 123 depositional environments in the Laingsburg area (Jones et al. 2013; 2015), but a delta124 front/shoreface nomenclature is maintained for the Tanqua area (Wild et al. 2009).

127 The stratigraphic units of the lower Waterford Formation are interpreted as basin margin clinothems, 128 the fundamental building blocks of basin margin development (e.g. Steel and Olsen 2002; Helland129 Hansen et al. 2012; Patruno et al. 2015) (Fig. 1). Wild et al. (2009) and Jones et al. (2013) recognized 130 multiple 10-100 m-thick clinothems along depositional dip profiles (Figs. 3, 4), in Tanqua and 131 Laingsburg respectively. The vertical profile, depositional setting and scale of these stratigraphic 132 packages are consistent with deltaic parasequences as described by Van Wagoner et al. (1990). 133 Constraining the complete topset, foreset and bottomset deposits for each individual clinothem is not 134 always possible. However, the basinward thickening of parasequences, defined by regional mudstone 135 units interpreted to contain the deepwater equivalent of flooding surfaces, can be recognized and 136 used to define clinothems (Dixon et al. 2012b; Jones et al. 2015). The first abrupt or significant change in the gradient can be used to interpret the location of successive shelf edge rollovers 138 (Southard and Stanley 1976), but the 'apparent' geometry of ancient shelf margins might be highly dependent on the choice of datum and the result of post-depositional factors, such as differential 140 sand/mud compaction and accumulated error when measuring thicknesses in the field. This 141 geometric criterion must be therefore used in combination with other observed features, which do not 142 independently point the shelf edge position, but that in conjunction indicate abrupt changes in 143 sedimentary facies and depositional architecture close to the shelf-edge rollover zone. These include 144 (i) extensional deformation (growth faults), (ii) widespread bypass features (gullies) and (iii) 145 progressive increase in sandstone turbidites beyond the rollover (see Jones et al. 2013).

146 In the up-dip exposures, clinothem thickness decreases stratigraphically upward from $\sim 50 \mathrm{~m}$ to $\sim 25 \mathrm{~m}$ 147 in Tanqua, and from $\sim 100 \mathrm{~m}$ to $\sim 20 \mathrm{~m}$ in Laingsburg (Table 2). The documented NE and E paleoflow 148 direction in both the Tanqua and Laingsburg depocenters is consistent with a NW-SE orientation of 
149 the reconstructed shelf margin, although with local irregularities and lateral variability as reported in 150 the Laingsburg depocenter (Jones et al. 2015) (Fig. 5).

\section{STRATIGRAPHIC ARCHITECTURE}

154 The lower Waterford Formation in the Laingsburg area comprises eight regionally-correlated 155 clinothems (Jones et al. 2015). The lower four units (WfC-1-4) show a progradational stacking pattern interpreted as a highstand systems tract (Jones et al., 2013). WfC 4 and 5 are separated by an 157 interpreted regressive surface of marine erosion (type-2 sequence boundary, Fig. 4) (Jones et al. 2013). Clinothems show an increasingly steep rising trajectory with the shelf-edge rollover of WfC 5 positioned almost directly on top of the rollover of WfC 4 (Fig. 4) (Jones et al. 2015). WfC 5 represents the final sand-dominated shoreface system established at the shelf-edge rollover, and with an overlying 5-10 m-thick basinward thickening mudstone is interpreted as a transgressive systems tract (TST) and associated maximum flooding surface (MFS) that marks the retreat of the system to an inner shelf position (Fig. 4). WfC 6 and 7 consist primarily of heterolithic shoreface/offshore transition (SOT) deposits with poorly developed amalgamated lower shoreface facies only observable in their proximal exposures (Figs. 5, 6,7). The seaward pinchout of the sand-rich shoreface facies of WfC 6 is $10-15 \mathrm{~km}$ updip from the shelf-edge rollover position of WfC 5, and the shoreface component of WfC 7 is progradational relative to WfC 6 but also fines and pinches out to a minimum of $5 \mathrm{~km}$ landward of the shelf-edge rollover of WfC 5 (Figs. 5, 7). The basinward stepping of WfC 6 and 7 suggests that the system returned to a progradational trend as part of the subsequent highstand systems tract. However, the lack of coarse-grained material in WfC 6 and 7 beyond the shelf-edge

171 rollover position of WfC 5 in some areas along the shelf margin (Figs. 5) indicates that the sand-rich components of WfC 6 and 7 remained on the inner shelf (shelf-confined; Fig. 1). Correlations along

173 the Zoutkloof area show that sand-rich shoreface facies associations of WfC 8 extend for $15 \mathrm{~km}$ beyond the last sand-defined shelf edge of WfC 5 (Jones et al. 2015) and well beyond the inner shelf

175 sand-rich pinch-outs of WfC 6 and 7 (Fig. 7). Therefore, during WfC 6, 7 and lower WfC 8 the shelfedge rollover prograded $\sim 15 \mathrm{~km}$ (distance from the lower sand-rich rollover position identified in WfC

1775 to the sand-rich shelf-edge rollover of WfC 8) through the accretion of mud under sea level highstand conditions. 
181 The stratigraphic architecture of the lower Waterford Formation clinothems (C1-C8, Fig. 3) in the 182 Tanqua depocenter is similar to that described in Laingsburg but the correlation between both 183 successions is not established due to the lack of absolute age control. Differences (Table 2) include 184 thinner clinothems combined with lower estimated gradients $\left(0.5^{\circ}\right.$ to $0.7^{\circ}$, using compacted 185 thicknesses) (see also Wild et al. 2009), and a thinner underlying channelized slope succession (Wild 186 et al. 2005; Hodgson et al. 2006), suggesting a lower-gradient margin and a shallower basin margin 187 relief in the Tanqua depocenter.

188 Clinothems C2-4 exhibit a strongly aggradational to progradational stacking pattern and rising 189 shoreline and shelf edge rollover trajectory, interpreted as part of a highstand systems tract (Wild et 190 al. 2009), culminating in the maximum regression point in C4-5, with the rollover located close to the 191 SL1 locality (Fig. 3). The sandstone pinch-out of the overlying clinothem C5 is positioned slightly 192 landward of the sand-rich rollover of C4, south of SL1-Bitterberg (T5), suggesting a turnaround to a 193 retrogradational stacking pattern. This, together with an overlying regionally extensive mudstone is 194 interpreted to be part of a transgressive systems tract (TST) and early HST, and contain an 195 associated MFS, at which time the shoreline stepped back onto a more landward shelf position (Fig. $1963)$.

197 Clinothem C6 consists of amalgamated organic-rich delta front/shoreface facies associations (Table 198 1) that are only recognized in the most proximal exposures (T2-T3, Fig. 3). The sand-rich component 199 of C6 fines and thins basinward, and pinches out between Vaalberg and Bitterberg (T4 and T5, Fig. 200 3), i.e., before the established shelf-edge rollover position of C5. Clinothem C7 prograded over C6 201 and its delta front/shoreface sandstones pinchout beyond the previous shelf-edge rollover position of 202 C5, reaching the westernmost edge of the study area in Katjiesberg (T7, Fig. 3). The progradational 203 stacking pattern of $\mathrm{C} 6$ and $\mathrm{C} 7$ is consistent with the lower part of a second highstand systems tract 204 after the regional transgressive event in C5. The absence of sand-rich C6 deposits basinward of the 205 rollover position of $\mathrm{C} 5$ is consistent with deltaic/shoreface sandstones confined in the inner shelf and 206 with a mudstone-dominated shelf edge and upper slope. Sand-rich facies associations in C7 can be 207 followed basinward for $10 \mathrm{~km}$ beyond the sand-rich rollover positions of C4 and C5 and well beyond 
the sandstone pinch out of $\mathrm{C} 6$ (Fig. 3). This indicates that during $\mathrm{C} 6$ and early $\mathrm{C} 7$ time, the shelf-edge rollover also prograded through the accretion of mud under sea level highstand conditions.

\section{MUDSTONE-DOMINATED SHELF EDGE DEPOSITS}

213 WfC 6 and 7 are well exposed in the Zoutkloof area of the Laingsburg depocenter (Fig. 6, see location 214 in Fig. 4A). Detailed outcrop observations just above shoreface-offshore transition (SOT, Table 1) deposits of WfC 5 reveal an 8 m-thick fining-upward package overlain by a 33 m-thick coarseningand thickening-upward package (Fig. 6). The lower package starts with highly bioturbated coarse siltstones, showing a distinctive mottled texture with an irregular distribution of sand grains within a 218 silty matrix. Overlying these siltstones are multiple surfaces with associated iron-rich nodular horizons, interpreted to record condensed sections and are therefore included in the upper part of the

220 TST associated with WfC 5 (Figs. 6, 7, Table 1). Just above the best developed of these surfaces, considered to be recording the maximum flooding surface, facies pass abruptly into darker, finer-

222 grained and laminated siltstones, rich in organics and mica. These thin beds feature mm-scale dominantly unidirectional to combined-flow tractional structures with little to no bioturbation,

224 interpreted as the oldest most distal deposits of WfC 6 (Fig. 6). Thin beds alternate with diffusely bedded structureless fine siltstones, and become progressively coarser and cleaner up section, losing

226 their organic content while retaining a low to moderate bioturbation index. An overlying pervasively bioturbated $1.2 \mathrm{~m}$-thick package is interpreted to record the transgressive top of WfC 6 . The overlying

228 WfC 7 succession coarsens- and thickens-upward from sandstones with symmetrically rippled tops to thicker-bedded sandstones with hummocky cross-stratification (Table 1). The stacking pattern and

230 facies characteristics of WfC 6 and 7 are consistent with an upward transition from offshore/distal prodelta mudstones deposited initially below storm wave base to progressively sandier and shallower 232 wave-influenced deposits (Fig. 6, Table 1). The soft-sediment deformation features observed in WfC 7 233 are interpreted to record delta front/shoreface collapse (Oliveira et al. 2011) (Fig. 7, Table 1). WfC 8 234 starts with moderately-bioturbated and laminated prodeltaic thin beds, but records a more abrupt transition into sand-rich shoreface facies associations (Fig. 6). 
238 Core observations of the SL1 research borehole (Wild et al. 2009) drilled close to the Bitterberg 239 locality $(T 5$, Figs. 3, 8) of the Tanqua depocenter allowed subtle variations in the characteristics of 240 fine-grained deposits in the C6-C7 succession to be documented (Fig. 8). The stratigraphic control 241 indicates that in the core, this mudstone-dominated package overlies the maximum flooding surface 242 above C5, and captures deposition across the shelf-edge rollover (Fig. 3). Analysis included detailed 243 (mm-scale) logging of the whole 40 m-thick C6-C7 package, with special attention to the stacking 244 pattern and sedimentological features of thin beds to allow an accurate description and interpretation 245 of processes (Fig. 8).

246 Observations reveal the presence of $\mathrm{mm}$ to $\mathrm{cm}$-scale organic and mica-rich laminated siltstone layers, 247 interbedded with few bioturbated and/or structureless mudstones (Fig. 8). Parallel- and ripple248 laminated siltstones show normal and/or inverse grading, and a range of internal erosion and traction 249 structures within a single bed, along with small-scale soft-sediment deformation (Fig. 8) towards the 250 basal contact of the beds. Sedimentary structures, when observed, mostly include undulate bedding, starved current ripples and apparent planar lamination (Schieber et al. 2010). Some beds show a

252 distinctive two-part organization with a clean, laminated silt-rich lower part, preserving primary structures and an erosive and/or loaded base (Fig. 8), overlain with a sharp contact by a finer and

254 darker poorly sorted/bioturbated upper section, rich in mud clasts and containing mica and plant debris (Fig. 9). Bioturbation intensity generally ranges from moderate to low (Bioturbation Index 0-2)

256 (e.g. Taylor et al. 2003). Evidence of combined-flow indicators can be inferred from low angle/undulated cross laminations in the coarser beds of these fine-grained intervals (Fig. 8).

260 The outcrop examples of Laingsburg WfC 6 and 7 in the Zoutkloof panel (Fig. 7) combined with the core observations of Tanqua C6 and C7 in the SL1 well (Fig. 8), offer the opportunity to study two unusual examples of fine-grained shelf to slope transitions. These mudstone thin beds are grouped according to their interpreted sedimentary processes and inferred position along the depositional 264 profile (Types A-D; Fig. 10).

265 Type- $A$ beds are mainly composed of coarse siltstone with sharp base and top, and combined- to 266 unidirectional-flow tractional structures. Type- $A$ beds dominate the upper (and more proximal) parts of mudstone-dominated clinothems in WfC 6-7 in Zoutkloof (Fig. 6) and in C6-7 in the SL1 well (Fig. 8), 
and are also commonly seen interbedded with wave-dominated sand-rich thin beds in shorefaceoffshore transition deposits (Fig. 6, Table 1). These beds (0.5-2 cm-thick) are interpreted to record the

270 most proximal expression of dilute silt-rich gravity-flows in distal prodelta/outer shelf settings, 271 sometimes under the effect of storm/waves (undulate cross laminations observed might be the 272 product of storm reworking), and with the sharp bed tops indicative of basinward bypass (Stevenson 273 et al. 2015) of finer particles (Fig. 10).

274 Type-B beds have sharp, erosive/loaded bases with a distinctive bipartite character that comprises a 275 lower (0.5-2 cm-thick) well-sorted silt-rich, parallel to low angle laminated part, overlain by a 276 mud/organic-rich poorly-sorted upper section (1-2 cm-thick; Fig. 10). The poorly sorted part commonly 277 drapes a scour surface (Fig. 9,). Type-B beds are interpreted to record a longitudinal change in flow 278 properties within the same event, associated with flow acceleration due to sediment entrainment and/or gradient increase at the shelf edge. This flow transformation is recorded in the sharp intra-bed 280 facies change from the clean and well-sorted laminated basal part to the poorly sorted argillaceous part overlying an erosion surface. The basal part is interpreted as the deposit of a waxing underflow, and the upper part as a muddy debrite, with the erosion surface between suggesting a phase of basinward sediment bypass. Type- $B$ beds dominate intermediate sections of the studied intervals 284 (Fig. 8).

285 Type-C beds form 2-4 cm-thick inverse-graded beds with a gradational base, relatively sharp, mudstone clast-rich tops sometimes overlain by a finer and moderately bioturbated normally graded upper part, and a general absence of bioturbation (Fig. 8). Their character suggests an accelerating/waxing flow origin and entrainment of seafloor material and/or lofted mud-size particles from the turbid ambient fluid (Fig. 10). The sharp tops suggest basinward sediment bypass. Type-C 290 beds are less common than other bed types, and occur in the lower parts of the studied sections, suggesting deposition occurred where gradient progressively increased towards the upper slope (Fig. 292 10).

293 Type-D beds are generally 0.5-7 cm-thick, sharp-based and normally graded with traction structures 294 and grade into well-developed mud-rich tops with moderate bioturbation (B.I. 2) and abundant organic debris and mica. They are interpreted to record deposition of the dilute part of a waning sediment 296 gravity flow across the shelf-to-slope transition (Fig. 10). Although Type-D beds are found throughout the entire succession, they are more common in the lower part of the studied sections (Fig. 8), 
suggesting they record deposition in a more distal setting under relatively quieter conditions. Locally, Type- $C$ and Type- $D$ beds combine to form inverse- to normally-graded beds, which has been used as diagnostic criteria for deposition from hyperpycnal flows (Mulder et al. 2003; Plink-Björklund and Steel 2004; Zavala et al. 2007).

\section{DISCUSSION}

Large-scale correlation within the lower Waterford Formation demonstrates that some periods of basin margin progradation were exclusively through the accretion of mud (clay and silt) across the shelf-edge rollover and onto the upper slope. In the Laingsburg depocenter, during WfC 6 and 7 and early WfC 8 , shelf margin accretion and progradation took place in the absence of coarse-grained sediment supply under flooded shelf conditions. Sufficient accommodation and shallow water depths led to the development of low-amplitude (5-30 m-thick) mud-rich and shelf-confined delta clinothems

311 (Figs. 1, 6). However, at this time the shelf-edge rollover prograded a minimum of 15 kilometers via 312 deposition of mud-rich flows, down dip from time equivalent shelf-confined sand-rich delta 313 fronts/shorefaces (Figs. 6, 10). During periods of high relative sea level, although the sand-rich 314 component of deltas mostly accumulates on the inner shelf (e.g. Porębski and Steel 2006), the shelf edge is still present as a physiographic feature, but is muddier and more attenuated (Olariu and Steel

316 2009). In the absence of absolute age control in the Karoo Basin the rates of aggradation and progradation cannot be constrained. These results contrast with 'classic' seismic sequence

318 stratigraphy, that was developed to understand and predict the spatial and temporal distribution of potential reservoir sand bodies in relation to accommodation history of basin margins (Vail et al. 1977;

320 Posamentier et al. 1988; Posamentier and Vail 1988; Van Wagoner et al. 1990). Therefore, depositional models have paid little attention to the large volume and processes of fine-grained

322 sediment delivery to build the shelf prism, and instead emphasize the timing of sand transfer to the 323 slope and basin floor, as a response to relative sea level change (e.g. Helland-Hansen and Hampson 324 2009). During periods of low relative sea level, the shelf margin position tends to move basinward, but part or all of the shelf may become exposed subaerially, and the shelf and shelf-edge rollover areas 326 will be subject to sediment bypass and local degradation (Ross et al. 1994; Hadler-Jacobsen et al. 2005; Ryan et al. 2009). 
330 Most studies of ancient clinothems and shelf margins focus on the process regime and architecture of 331 sand-rich deposits to support shelf-edge rollover identification (e.g. Plink-Björklund and Steel 2002; 332 Mellere et al. 2003; Pyles and Slatt 2007; Uroza and Steel 2008; Hubbard et al. 2010; Dixon et al. 333 2012a; Jones et al. 2013). The present study demonstrates that shelf-edge rollovers are not always 334 defined by sand-rich deposits, yet can still be identified at outcrop based on geometry and detailed sedimentology. Under flooded shelf conditions, the mud-rich extended bottomset component of 336 deltaic clinothems may reach the upper slope, to build fine-grained shelf-edge rollovers and basin margin clinothem foresets that prograde basinward. This occurs when the sand-rich topset and 338 foreset component of delta-scale clinothems is confined to the inner part of the shelf (Fig. 1). Analysis of the lower Waterford Formation clinothems highlights a potential limitation of shelf-edge trajectory

340 analysis; delivery systems are observed to change laterally from shelf-confined to shelf-edge (e.g.

341 Sanchez et al. 2012; Jones et al. 2015) (Figs. 1, 11), however the clinothem trajectory may remain 342 consistently progradational. An example of this can be found in the Upper Cretaceous Fox Hills 343 Formation (Wyoming, USA), where, although most of prograding clinothems are dominated by sand, 344 some examples have shelf edge rollovers dominated by mud (clinothems C06, C07 and C12, Olariu 345 et al. 2012). The expression of shelf-edge rollovers and parasequence boundaries of muddy 346 clinothems are challenging to identify, and the time they represent is difficult to constrain (Bohacs 347 1998). This is particularly true in subsurface studies, due to the complex recognition of impedance 348 contrasts (Miller et al. 2013). As in the Waterford Formation, under relative sea level highstand conditions, the delta top sand-rich components of some parasequences can be confined in inner shelf

350 positions, remaining below seismic resolution, but the shelf margin can still prograde through the accretion of mud (Fig. 11). The position of highstand deposits relative to the shelf margin can be

352 problematic in exploration studies, because muddy parasequences may have laterally extensive, comparatively sand-dominated topsets (Figs. 5,11 ) and therefore require the presence of regional,

354 transgressive mudstones to develop effective seals.

355

356

Sediment transport on a high-energy muddy shelf 
357 The integration of outcrop data with detailed core analysis shows that mud-dominated shelf margin 358 progradation was the result of deposition of muddy and organic-rich sediment gravity flows. The 359 significant amount of plant debris and mica in some beds indicates a continental origin of mud, 360 possibly from hyperpycnal river plumes (Mulder and Alexander 2001; Mulder et al. 2003; Bouma and 361 Scott 2004; Plink-Björklund and Steel 2004; Zavala et al. 2006a; 2006b; Bhattacharya and MacEachern 2009; Zavala et al. 2012). However, the common occurrence of wave/storm processes 363 that influenced the deposition of sand-rich deposits in shoreface and shoreface-offshore transition settings (Table 1) (Jones et al. 2015), combined with a relatively low gradient (Table 2), is not consistent with the characteristics of margins where fine-grained sedimentation is associated with recurrent and sustained hyperpycnal discharges to the shelf edge (Mutti et al. 1996; Bentley 2003;

367 Mulder et al. 2003; Mutti et al. 2003; Plink-Björklund and Steel 2004; Friedrichs and Scully 2007). Wave/storm processes are therefore advocated to be the main mechanism that kept unconsolidated silt and flocculated clay fraction in suspension, or re-suspended (e.g. Traykovski et al. 2000; Pattison 2008; Macquaker et al. 2010). Mud particles that accumulate as floccules or organo-mineralic aggregates (Plint 2014) act hydrodynamically as silt or sand grains (Schieber et al. 2007). This is supported by the ubiquity of tractional structures observed within the thin mudstone beds. Wave enhancement of gravity flows or storm re-suspension of previously-deposited sediment can occur before, during, or shortly after river flood events (Ogston et al. 2000; Traykovski et al. 2000; Fan et al. 2004), but the process is more commonly identified in systems that are not able to deliver significant amounts of new mud to the shelf (Bentley et al. 2006). The paucity of combined-flow indicators in bed Types $B$ to $D$ (Fig. 10) contrasts with their presence in Type $A$ beds and their presence in the shoreface and shoreface-offshore transition sandy counterparts (Fig. 6 and Table 1). This is interpreted to indicate that, although waves/storms played an important role keeping mud in suspension across the shelf, deposition of the finest particles in the studied sections took place mostly below storm wave base as sediment gravity flows (e.g. Pattison 2005). Erosive and sharp boundaries within beds, and internal scours draped by poorly-sorted mudstones suggest sediment bypass and downslope transformation from waxing to waning gravity-driven flows. This, together with the low bioturbation intensity and diversity within the thin, silty beds, reflects environmental stresses and high sedimentation rates in outer shelf to upper slope settings of mud-dominated clinoforms. 
388 Three parasequences from exhumed and well-constrained basin margin clinothems of the Permian 389 Waterford Formation, in adjacent depocenters of the Karoo Basin (South Africa), provide the first examples of mudstone-dominated shelf-edge rollover deposits documented in outcrop and core. This dataset has allowed the timing and processes of fine-grained sediment transport across the shelf and onto the slope to be assessed. The study demonstrates that some periods of shelf-edge progradation occurred through the accretion of mud when the sand-rich part of wave-influenced deltas was positioned on the inner shelf. Detailed analysis of offshore mudstones suggests that recurrent supply to outer shelf and upper slope regions was by micaceous and organic-rich fluid mud that was kept in suspension or re-suspended from inner shelf positions during storms and transported across the low gradient shelf as dilute silt-rich gravity flows. Thin bed characteristics at the shelf-edge rollover and upper slope include soft-sediment deformation, evidence of sediment bypass including sharp contacts, internal erosions and traction structures and a subtle downdip facies changes within low density, silty turbidites. This work demonstrates that processes responsible for the transport and deposition of fine-grained material across and beyond the shelf edge play a fundamental role in basin margin development. The documentation of mud-rich shelf to slope transitions is significant for outcrop and subsurface investigations, because clinothems are not always defined by sand-rich shelfedge rollovers, and significant basin margin progradation can also occur in the absence of coarsegrained sediment supply. This implies potential risks in the identification of shelf-edge rollover positions from presence of sand alone, and in the use of trajectory analysis to interpret relative sealevel changes and to predict down dip sand supply.

\section{ACKNOWLEDGEMENTS}

410 The authors thank the Slope project Phase 4 sponsors for financial support: Anadarko, BHP Billiton, 411 BP, ConocoPhillips, E-ON, Engie, Maersk, Murphy, Nexen-CNOOC, Petrobras, Shell, Statoil, Total, 412 VNG Norge and Woodside. De Ville Wickens is acknowledged for his logistical support and insightful 413 discussions in the field. Landowners are thanked for permission to their land. Luz Gomis, Colleen 414 Kurcinka, Daniel Bell, Lewis Burden, Eoin Dunlevy and Xavier Solé are thanked for their assistance. 415 This manuscript has benefited from the insightful comments and reviews of Andrea Fildani, Cornel Olariu, Guy Plint and Carlo Messina. 
417

418 
421 Аввотт, S.T., 2000, Detached mud prism origin of highstand systems tracts from mid-Pleistocene sequences, Wanganui Basin, New Zealand: Sedimentology, v. 47, p. 15-29.

423 Ainsworth, R.B., VAKarelov, B.K., and NAnson, R.A., 2011, Dynamic spatial and temporal prediction of changes in depositional processes on clastic shorelines: Toward improved subsurface uncertainty reduction and management: AAPG Bulletin, v. 95, p. 267-297.

Allison, M.A., and NeILL, C.F., 2003, Development of a modern subaqueous mud delta on the Atchafalaya Shelf, Louisiana, in Scott, E.D., Bouma, A.H., and Bryant, W.R., eds., Siltstones, Mudstones and Shales: Depositional Processes and Characteristics: SEPM, CD-ROM, p. 2334.

Allison, M.A., and NitTrouer, C.A., 1998, Identifying accretionary mud shorefaces in the geologic record: insights from the modern Amazon dispersal system, in Schieber, J., Zimmerle, W., and S. Sethi, P., eds., Shales and mudstones: Recent Progress in Shale Research: Stuttgart, Schweizerbart'sche Verlagsbuchhandlung, Stuttgart, Germany, p. 147-161.

AuguStinUS, P.G.E.F., 1989, Cheniers and chenier plains: a general introduction: Marine Geology, v. 90, p. 219-229.

BENTLEY, S.J., 2003, Wave-current dispersal of fine-grained fluvial sediments across continental

Bentley, S.J., Sheremet, A., and JAeger, J.M., 2006, Event sedimentation, bioturbation and preserved sedimentary fabric: field and model comparisons in three contrasting marine settings: Continental Shelf Research, v. 26, p. 2108-2124.

BHATTACHARYA, J.P., and MACEACHERN, J.A., 2009, Hyperpycnal rivers and prodeltaic shelves in the Cretaceous seaway of North America: Journal of Sedimentary Research, v. 79, p. 184-209.

BoHACS, K.M., 1998, Contrasting expressions of depositional sequences in mudrocks from marine to non marine environs, in Schieber, J., Zimmerle, W., and Sethi, P.S., eds., Shales and mudstones: Recent Progress in Shale Research: Schweizerbart'sche Verlagsbuchhandlung, Stuttgart, Germany, p. 33-78. 
BOHACS, K.M., LAZAR, O.R., and DEMKO, T.M., 2014, Parasequence types in shelfal mudstone strataQuantitative observations of lithofacies and stacking patterns, and conceptual link to modern depositional regimes: Geology, v. 42, p. 131-134.

BoumA, A.H., and ScotT, E.D., 2004, A review of knowledge about fine-grained sediments: mudstones, siltstones and shales, in Scott, E.D., and Bouma, A.H., eds., Depositional Processes and Reservoir Characteristics of Siltstones, Mudstones and Shales, Volume 2: SEPM, CD-ROM, p. 9-23.

BURGESS, P.M., and HoviUS, N., 1998, Rates of delta progradation during highstands: consequences for timing of deposition in deep-marine systems: Journal of the Geological Society, v. 155, p.

Carvajal, C., Steel, R., and Petter, A., 2009, Sediment supply: The main driver of shelf-margin growth: Earth-Science Reviews, v. 96, p. 221-248.

Cattaneo, A., Correggiari, A., Langone, L., and Trincardi, F., 2003, The late-Holocene Gargano subaqueous delta, Adriatic shelf: sediment pathways and supply fluctuations: Marine Geology, v. 193, p. 61-91.

473 Cole, D.I., and WHIPPLINGER, P.E., 2001, Sedimentology and molybdenum potential Beaufort Group in the Karoo Basin: Council for Geoscience, Geological Survey of South Africa. Memoir 80.

475 Covault, J.A., Romans, B.W., and Graham, S.A., 2009, Outcrop Expression of a Continental-MarginScale Shelf-Edge Delta from the Cretaceous Magallanes Basin, Chile: Journal of Sedimentary Research, v. 79, p. 523-539. 
DALRYMPLE, R.W., and CUMmings, D.I., 2005, The offshore transport of mud: why it doesn't happen and the stratigraphic implications: Geological Society of America Abstracts with Programs, v. 37, p. 403.

Damuth, J.E., Flood, R.D., Kowsmann, R.O., Belderson, R.H., and Gorini, M.A., 1988, Anatomy and growth pattern of Amazon deep-sea fan as revealed by long-range side-scan sonar (GLORIA) and high resolution seismic studies.: AAPG Bulletin, v. 72, p. 885-911.

DixON, J.F., SteEL, R.J., and OlARIU, C., 2012a, River-dominated, shelf-edge deltas: delivery of sand across the shelf break in the absence of slope incision: Sedimentology, v. 59, p. 1133-1157.

DixON, J.F., STEEL, R.J., and OLARIU, C., 2012b, Shelf-edge delta regime as a predictor of deep-water deposition: Journal of Sedimentary Research, v. 82, p. 681-687.

DRISCOLL, N.W., and KARNER, G.D., 1999, Three-dimensional quantitative modeling of clinoform development: Marine Geology, v. 154, p. 383-398.

Fan, S., Swift, D.J.P., Traykovski, P., Bentley, S., Borgeld, J.C., Reed, C.W., and Niedoroda, A.W., 2004, River flooding, storm resuspension, and event stratigraphy on the northern California shelf: observations compared with simulations: Marine Geology, v. 210, p. 17-41.

Fildani, A., Drinkwater, N.J., Weislogel, A., Mchargue, T., Hodgson, D.M., and Flint, S.S., 2007, Age Controls on the Tanqua and Laingsburg Deep-Water Systems: New Insights on the Evolution and Sedimentary Fill of the Karoo Basin, South Africa: Journal of Sedimentary Research, v. 77, p. 901-908.

Fildani, A., Weislogel, A., Drinkwater, N.J., Mchargue, T., Tankard, A., Wooden, J., Hodgson, D.,

Flint, S.S., Hodgson, D.M., Sprague, A.R., Brunt, R.L., Van der Merwe, W.C., Figueiredo, J., Prélat, A., Box, D., Di Celma, C., and Kavanagh, J.P., 2011, Depositional architecture and sequence stratigraphy of the Karoo basin floor to shelf edge succession, Laingsburg

504 FriedRICHS, C.T., and SCULly, M.E., 2007, Modeling deposition by wave-supported gravity flows on 505 the Po River prodelta: from seasonal floods to prograding clinoforms: Continental Shelf Research, v. 27, p. 322-337. 
507 GHAdEER, S.G., and MACQUAKER, J.H., 2011, Sediment transport processes in an ancient muddominated succession: a comparison of processes operating in marine offshore settings and anoxic basinal environments: Journal of the Geological Society, v. 168, p. 1121-1132.

Hadler-Jacobsen, F., Johannessen, E.P., Ashton, N., Henriksen, S., Johnson, S.D., and KRISTENSEN, J.B., 2005, Submarine fan morphology and lithology distribution: a predictable function of sediment delivery, gross shelf-to-basin relief, slope gradient and basin

HaRAZIM, D., and MclLRoY, D., 2015, Mud-Rich Density-Driven Flows Along an Early Ordovician Storm-Dominated Shoreline: Implications for Shallow-Marine Facies Models: Journal of Sedimentary Research, v. 85 , p. 509-528.

HARMS, J.C., Southard, J.B., Spearing, D.R., and WAlKER, R.G., 1975, Depositional environments as interpreted from primary sedimentary structures and stratification sequences. SEPM Short Course Notes no. 2, 161 p.

HARMS, J.C., SOUthARD, J.B., and WALKER, R.G., 1982, Structures and sequences in clastic rocks. SEPM Short Course Notes no. 9, 249 p.

Helland-Hansen, W., and Hampson, G.J., 2009, Trajectory analysis: concepts and applications: Basin Research, v. 21, p. 454-483.

Helland-Hansen, W., Steel, R.J., and Sømme, T.O., 2012, Shelf genesis revisited: Journal of Sedimentary Research, v. 82, p. 133-148.

Henriksen, S., Hampson, G.J., Helland-Hansen, W., Johannessen, E.P., and Steel, R.J., 2009, Shelf edge and shoreline trajectories, a dynamic approach to stratigraphic analysis: Basin Research, v. 21, p. 445-453.

HenRiksen, S., Helland-Hansen, W., and Bullimore, S., 2011, Relationships between shelf-edge

533 Hill, P.S., Fox, J.M., Crockett, J.S., Curran, K.J., Friedrichs, C.T., Geyer, W.R., Milligan, T.G., Ogston, A.S., Puig, P., Scully, M.E., Traykovski, P.A., and Wheatcroft, R.A., 2009, 

Sedimentation, Blackwell Publishing Ltd., p. 49-99.

538 Hodgson, D.M., DI Celma, C.N., BRUnt, R.L., and Flint, S.S., 2011, Submarine slope degradation and aggradation and the stratigraphic evolution of channel-levee systems: Journal of the Geological Society, v. 168, p. 625-628.

Hodgson, D.M., Flint, S.S., Hodgetts, D., Drinkwater, N.J., Johannessen, E.P., and LUthi, S.M., 2006, Stratigraphic Evolution of Fine-Grained Submarine Fan Systems, Tanqua Depocenter, Karoo Basin, South Africa: Journal of Sedimentary Research, v. 76, p. 20-40.

Hubbard, S.M., Fildani, A., Romans, B.W., Covault, J.A., and McHargue, T.R., 2010, High-relief slope clinoform development: insights from outcrop, Magallanes Basin, Chile: Journal of Sedimentary Research, v. 80, p. 357-375.

ICHASO, A.A., and DALRYMPLE, R.W., 2009, Tide- and wave-generated fluid mud deposits in the Tilje Formation (Jurassic), offshore Norway: Geology, v. 37, p. 539-542.

JOHANNESSEN, E.P., and SteEL, R.J., 2005, Shelf-margin clinoforms and prediction of deepwater sands: Basin Research, v. 17, p. 521-550.

Johnson, M.R., van VuURen, C.J., Visser, J.N.J., Cole, D.I., Wickens, H.D.V., Christie, A.D.M., and RoberTS, D.L., 1997, The foreland Karoo Basin, South Africa in Selley, R.C. (ed.) African Basins. Sedimentary Basins of the World. Amsterdam, Elsevier Science, 3, p. 269-317.

Jones, G.E.D., Hodgson, D.M., and FLINT, S.S., 2013, Contrast in the process response of stacked clinothems to the shelf-slope rollover: Geosphere, v. 9, p. 299-316.

Jones, G.E.D., Hodgson, D.M., and FLINT, S.S., 2015, Lateral variability in clinoform trajectory, process regime, and sediment dispersal patterns beyond the shelf-edge rollover in exhumed basin margin-scale clinothems: Basin Research, v. 27, p. 657-680.

Kineke, G., Sternberg, R., Trowbridge, J., and Geyer, W., 1996, Fluid-mud processes on the Amazon continental shelf: Continental Shelf Research, v. 16, p. 667-696.

Kineke, G., Woolfe, K., Kuehl, S., Milliman, J., Dellapenna, T., and Purdon, R., 2000, Sediment export from the Sepik River, Papua New Guinea: evidence for a divergent sediment plume:

564 KueHL, S.A., LeVY, B.M., Moore, W.S., and Allison, M.A., 1997, Subaqueous delta of the Ganges565 Brahmaputra river system: Marine Geology, v. 144, p. 81-96. 
Kuehl, S.A., NitTrouer, C.A., Allison, M.A., Faria, L.E.C., Dukat, D.A., Jaeger, J.M., Pacioni, T.D., FigueIREDO, A.G., and UNDERKOFFleR, E.C., 1996, Sediment deposition, accumulation, and seabed dynamics in an energetic fine-grained coastal environment: Continental Shelf Research, v. 16, p. 787-815.

LiU, J., Milliman, J., and GaO, S., 2001, The Shandong mud wedge and post-glacial sediment accumulation in the Yellow Sea: Geo-Marine Letters, v. 21, p. 212-218.

LIU, J.P., Xu, K.H., LI, A.C., Milliman, J.D., VelozZI, D.M., XIAO, S.B., and Yang, Z.S., 2007, Flux and fate of Yangtze River sediment delivered to the East China Sea: Geomorphology, v. 85, p. 208-224.

MACKAY, D.A., and DalRYMPLE, R.W., 2011, Dynamic mud deposition in a tidal environment: the record of fluid-mud deposition in the Cretaceous Bluesky Formation, Alberta, Canada: Journal of Sedimentary Research, v. 81, p. 901-920.

MAcquakeR, J.H., TAYLOR, K.G., and GaWthORPE, R.L., 2007, High-resolution facies analyses of mudstones: implications for paleoenvironmental and sequence stratigraphic interpretations of offshore ancient mud-dominated successions: Journal of Sedimentary Research, v. 77, p. 324-339.

MACQUAKER, J.H.S., BENTLEY, S.J., and BoHACS, K.M., 2010, Wave-enhanced sediment-gravity flows and mud dispersal across continental shelves: Reappraising sediment transport processes operating in ancient mudstone successions: Geology, v. 38, p. 947-950.

MACQUAKER, J.H.S., and BOHACS, K.M., 2007, On the Accumulation of Mud: Science, v. 318, p. 17341735.

McAnally, W., Friedrichs, C., Hamilton, D., Hayter, E., Shrestha, P., Rodriguez, H., Sheremet,

MCCAVE, I.N., 1972, Transport and escape of fine-grained sediment from shelf areas, in Swift, D.J.P.,

594 McCuBbIN, D.G., 1982, Barrier-island and strand-plain facies, in Scholle, P.A., and Spearing, D., eds., 
McKay, M.P., Weislogel, A.L., Fildani, A., Brunt, R.L., Hodgson, D.M., and Flint, S.S., 2015, U-PB zircon tuff geochronology from the Karoo Basin, South Africa: implications of zircon recycling on stratigraphic age controls: International Geology Review, v. 57, p. 393-410.

Mellere, D., BRedA, A., and SteEL, R.J., 2003, Fluvial-incised shelf-edge deltas and linkage to upperslope channels (Central Tertiary Basin, Spitsbergen): Shelf-Margin Deltas and Linked Downslope Petroleum Systems: Global Significance and Future Exploration Potential, Gulf Coast Section. 23rd Annual Research Conference Houston, Texas, p. 231-266.

Michels, K.H., KudRASS, H.R., HüBscher, C., Suckow, A., and Wiedicke, M., 1998, The submarine delta of the Ganges-Brahmaputra: cyclone-dominated sedimentation patterns: Marine Geology, v. 149, p. 133-154.

Miller, K.G., Browning, J.V., Mountain, G.S., BAssetti, M.A., MonteVerde, D., KatZ, M.E., Inwood, J., LOFI, J., and PROUST, J.-N., 2013, Sequence boundaries are impedance contrasts: Coreseismic-log integration of Oligocene-Miocene sequences, New Jersey shallow shelf: Geosphere, v. 9, p. 1257-1285.

MORTON, R.A., and SUTER, J.R., 1996, Sequence Stratigraphy and Composition of Late Quaternary Shelf-Margin Deltas, Northern Gulf of Mexico: AAPG Bulletin, v. 80, p. 505-530.

Mountain, G.S., Proust, J.-N., McInRoy, D., and CotterilL, C., 2010, Proceedings of the Integrated Ocean Drilling Program, Volume 313: Tokyo, Integrated Ocean Drilling Program Management International, Inc.

Mulder, T., and AleXANDER, J., 2001, The physical characteristics of sub-aqueous sedimentary density flows and their deposits: Sedimentology, v. 48, p. 269-299.

Mulder, T., SyVITSKI, J.P.M., Migeon, S., FAugėReS, J.C., and SAVoYe B., 2003, Hyperpycnal turbidity

620 Muto, T., and SteEL, R.J., 2002, In Defense of Shelf Edge Delta Development during Falling and Lowstand of Relative Sea Level: The Journal of Geology, v. 110, p. 421-436.

622 Mutti, E., Davoli, G., TinterRI, R., and Zavala, C., 1996, The importance of fluvio-deltaic systems dominated by catastrophic flooding in tectonically active basins: Memorie di Scienze Geologiche, v. 48, p. 233-291. 
625 Mutti, E., Tinterri, R., Benevelli, G., Biase, D.D., and Cavanna, G., 2003, Deltaic, mixed and turbidite sedimentation of ancient foreland basins: Marine and Petroleum Geology, v. 20, p. 733-755.

628 NAKAJIMA, T., 2006, Hyperpycnites deposited $700 \mathrm{~km}$ away from river mouths in the Central Japan Sea: Journal of Sedimentary Research, v. 76, p. 59-72.

630 NemeC, W., 1995, The dynamics of deltaic suspension plumes, in Oti, M.N., and Postma, G., eds., 631 Geology of Deltas, AA Balkema, Rotterdam, p. 31-93.

632 Nittrouer, C., Kuehl, S., DeMaster, D., and Kowsmann, R., 1986, The deltaic nature of Amazon shelf sedimentation: Geological Society of America Bulletin, v. 97, p. 444-458.

634 Ogston, A.S., Cacchione, D.A., Sternberg, R.W., and Kineke, G.C., 2000, Observations of storm and river flood-driven sediment transport on the northern California continental shelf:

637 OlaRIU, C., and SteEL, R.J., 2009, Influence of point-source sediment-supply on modern shelf-slope morphology: implications for interpretation of ancient shelf margins: Basin Research, v. 21, p. 484-501.

640 Olariu, M.I., Carvajal, C.R., Olariu, C., and Steel, R.J., 2012, Deltaic process and architectural evolution during cross-shelf transits, Maastrichtian Fox Hills Formation, Washakie Basin, Wyoming: AAPG Bulletin, v. 96, p. 1931-1956.

Oliveira, C.M.M., Hodgson, D.M., and Flint, S.S., 2011, Distribution of soft-sediment deformation structures in clinoform successions of the Permian Ecca Group, Karoo Basin, South Africa: Sedimentary Geology, v. 235, p. 314-330.

PARSONS, J.D., BUSH, J., and SYVITSKI, J.P.M., 2001, Hyperpycnal plume formation from riverine outflows with small sediment concentrations: Sedimentology, v. 48, p. 465-478.

PATRUNO, S., HAMPSON, G.J., and JACKSON, C.A.L., 2015, Quantitative characterisation of deltaic and subaqueous clinoforms: Earth-Science Reviews, v. 142, p. 79-119.

PATtISON, S., 2005, Isolated highstand shelf sandstone body of turbiditic origin, lower Kenilworth

653 PATtison, S., 2008, Role of wave-modified underflows in the across-shelf transport of fine-grained sediments: Examples from the Book Cliffs, Utah, AAPG Hedberg Conference Sediment 

Ushuaia-Patagonia, Argentina.

657 PLinK-BJÖRKLUND, P., and Steel, R., 2002, Sea-level fall below the shelf edge, without basin-floor fans: Geology, v. 30, p. 115-118.

Plink-BJöRkLUnd, P., and Steel, R.J., 2004, Initiation of turbidity currents: Outcrop evidence for Eocene hyperpycnal flow turbidites: Sedimentary Geology, v. 165, p. 29-52.

PLINT, A.G., 2014, Mud dispersal across a Cretaceous prodelta: storm-generated, wave-enhanced sediment gravity flows inferred from mudstone microtexture and microfacies: Sedimentology, v. 61, p. $609-647$.

Plint, A.G., MAcquaker, J.H., and VARBAN, B.L., 2012, Bedload transport of mud across a wide, storm-influenced ramp: Cenomanian-Turonian Kaskapau Formation, Western Canada Foreland Basin: Journal of Sedimentary Research, v. 82, p. 801-822.

Plint, A.G., Tyagl, A., Hay, M.J., Varban, B.L., Zhang, H., and Roca, X., 2009, Clinoforms, paleobathymetry, and mud dispersal across the Western Canada Cretaceous foreland basin:

PoRĘBSKI, S.J., and StEel, R.J., 2006, Deltas and sea-level change: Journal of Sedimentary Research, v. 76, p. 390-403.

Posamentier, H.W., JerVey, M.T., and Vall, P.R., 1988, Eustatic controls of clastic deposition I Conceptual framework, in Wilgus, C.K., Hastings, B.S., Kendall, C.G., Posamentier, H.W.,

Posamentier, H.W., and Vall, P.R., 1988, Eustatic controls of clastic deposition II - Sequence and systems tract model, in Wilgus, C.K., Hastings, B.S., Kendall, C.G., Posamentier, H.W., Ross,

PYLES, D.R., and SLATT, R.M., 2007, Applications to understanding shelf edge to base-of-slope changes in stratigraphic architecture of prograding basin margins: Stratigraphy of the Lewis Shale, Wyoming, USA, in Nilsen, T.H., Shew, R.D., Steffens, G.S., and Studlick, J.R.J., eds., Atlas of Deepwater Outcrops: AAPG Studies in Geology 56, p. 485-489. 
685 PYSKLYWEC, R.N., and MITROVICA, J.X., 1999, The role of subduction-induced subsidence in the evolution of the Karoo Basin: Journal of Geology, v. 107, p. 155-164.

687 REINECK, H.-E., and SINGH, I.B., 1973, Depositional sedimentary environments. New York, SpringerVerlag, $439 \mathrm{p}$.

RINE, J., and GINSBURG, R.N., 1985, Depositional facies of a mud shoreface in Suriname, South America--a mud analogue to sandy, shallow-marine deposits: Journal of Sedimentary Research, v. 55, p. 633-652.

Ross, W.C., Halliwell, B.A., MAY, J.A., WATTS, D.E., and SYVITSKI, J.P.M., 1994, Slope readjustment: a new model for the development of submarine fans and aprons: Geology, v. 22, p. 511-514.

Rotondo, K.A., and BentLeY, S.J., 2003, Marine dispersal of fluvial sediments as fluid muds: old concept, new significance, in Scott, E.D., Bouma, A.H., and Bryant, W.R., eds., Siltstones, Mudstones and Shales: Depositional Processes and Characteristics: SEPM, CD-ROM, p. 2334.

Rubidge, B.S., Hancox, P.J., and Catuneanu, O., 2000, Sequence analysis of the Ecca-Beaufort

Ryan, M.C., Helland-Hansen, W., Johannessen, E.P., and Steel, R.J., 2009, Erosional vs. 702 accretionary shelf margins: the influence of margin type on deepwater sedimentation: an example from the Porcupine Basin, offshore western Ireland: Basin Research, v. 21, p. 676703.

Sanchez, C.M., Fulthorpe, C.S., and Steel, R.J., 2012, Miocene shelf-edge deltas and their impact on deepwater slope progradation and morphology, Northwest Shelf of Australia: Basin Research, v. 24, p. 683-698.

Schieber, J., Southard, J., and Thaisen, K., 2007, Accretion of Mudstone Beds from Migrating Floccule Ripples: Science, v. 318, p. 1760-1763.

Schieber, J., and SoUtHARD, J.B., 2009, Bedload transport of mud by floccule ripples-Direct observation of ripple migration processes and their implications: Geology, v. 37, p. 483-486.

Schieber, J., Southard, J.B., and Schimmelmann, A., 2010, Lenticular shale fabrics resulting from intermittent erosion of water-rich muds-interpreting the rock record in the light of recent flume experiments: Journal of Sedimentary Research, v. 80, p. 119-128. 
SCHIEBER, J., and YAWAR, Z., 2009, A new twist on mud deposition-mud ripples in experiment and rock record: The Sedimentary Record, v. 7, p. 4-8.

Slingerland, R., Driscoll, N.W., Milliman, J.D., Miller, S.R., and Johnstone, E.A., 2008, Anatomy and growth of a Holocene clinothem in the Gulf of Papua: Journal of Geophysical Research: Earth Surface, v. 113, p. F01S13.

SOUTHARD, J.B., and StANLEY, D.J., 1976, Shelf-break processes and sedimentation, in Stanley, D.J., and Swift, D.J.P., eds., Marine Sediment Transport and Environmental Management. WileyInterscience, New York, p. 351-377.

SOYINKA, O., and SLATT, R.M., 2008, Identification and microstratigraphy of hyperpycnites and turbidites in Cretaceous Lewis Shale, Wyoming: Sedimentology, v. 55, p. 1117-1133.

Steel, R., Mellere, D., Plink-Björklund, P., Crabaugh, J., Deibert, J., and Shellpeper, M., 2000,

StEeL, R., and OLSEN, T., 2002, Clinoforms, clinoform trajectories and deepwater sands.: GCSSEPM Foundation 22nd Annual Research Conference Special Publication, CD. GCSSEPM, p. 367381.

734

Steel, R., Porebski, S., Plink-Bjorklund, P., Mellere, D., and Schellpeper, M., 2003, Shelf-edge Deltas vs rivers on the shelf edge: their relative contributions to the growth of shelf-margins and basin-floor fans (Barremian and Eocene, Spitsbergen). in Weimer, P., Slatt, R.M., Coleman, J., Rosen, N.C., Nelson, H., Bouma, A.H., Styzen, M.J., and Lawrence, D.T., eds., Transactions Gulf Coast SEPM Annual Conference, Houston. CD, p. 981- 1009.

Stevenson, C.J., Jackson, C.A.-L., Hodgson, D.M., Hubbard, S.M., and Eggenhuisen, J.T., 2015, Deep-water sediment bypass: Journal of Sedimentary Research, v. 85, p. 1058-1081.

TA, T.K.O., Nguyen, V.L., TATEISHI, M., Kobayashi, I., and Saito, Y., 2005, Holocene Delta Evolution and Depositional Models of the Mekong River Delta, Southern Vietnam, in Liviu Giosan, and Janok P. Bhattacharya, eds., River Deltas-Concepts, Models, and Examples. SEPM Special Publication No. 83, p. 453-466.

Tankard, A., Welsink, H., Aukes, P., Newton, R., and Stettler, E., 2009, Tectonic evolution of the Cape and Karoo basins of South Africa: Marine and Petroleum Geology, v. 26, p. 1379-1412. 
TAYLOR, A., GoldRING, R., and GoWLAND, S., 2003, Analysis and application of ichnofabrics: EarthScience Reviews, v. 60, p. 227-259.

TRAYKovski, P., GeYeR, W.R., IRISH, J., and LYNCH, J., 2000, The role of wave-induced density-driven fluid mud flows for cross-shelf transport on the Eel River continental shelf: Continental Shelf Research, v. 20, p. 2113-2140.

UROZA, C.A., and STEEL, R.J., 2008, A highstand shelf-margin delta system from the Eocene of West Spitsbergen, Norway: Sedimentary Geology, v. 203, p. 229-245.

Vall, P.R., Mitchum, R.M.J., Tood, R.G., Widmier, J.M., Thompson, S., SAngree, J.B., BubB, J.N., and HATLELID, W.G., 1977, Seismic stratigraphy and global changes of sea level, in Payton, C.E., ed., Seismic Stratigraphy. Application to Hydrocarbon Exploration, AAPG Memoir, 26, p. $49-205$.

Van Wagoner, J.C., Mitchum, R.M., Campion, K.M., and Rahmanian, V.D., 1990, Siliciclastic sequence stratigraphy in well logs, cores, and outcrops. American Association of Petroleum Geologists Methods in Exploration Series, No. 7: Tulsa, Oklahoma, 55 p.

VARBAN, B.L., and PLINT, G.A., 2008, Palaeoenvironments, palaeogeography, and physiography of a large, shallow, muddy ramp: Late Cenomanian-Turonian Kaskapau Formation, Western Canada foreland basin: Sedimentology, v. 55, p. 201-233.

Veevers, J.J., Cole, D.I., and Cowan, E.J., 1994, Southern Africa: Karoo Basin and Cape Fold Belt, in Veevers, J.J., and Powell, C.M., eds., Permian-Triassic Pangean basins and foldbelts along the Panthalassan Margin of Gondwanaland. Geological Society America Memoir 184,

VISSER, J.N.J., 1997, Deglaciation sequences in the Permo-Carboniferous Karoo and Kalahari basins of southern Africa: a tool in the analysis of cyclic glaciomarine basin fills: Sedimentology, v.

VISSER, J.N.J., and PRAEKelt, H.E., 1996, Subduction, mega-shear systems and Late Palaeozoic 770 basin development in the African segment of Gondwana: Geologische Rundschau, v. 85, p. 632-646.

Walsh, J., Nittrouer, C., Palinkas, C., Ogston, A., Sterniberg, R., and Brunskill, G., 2004, Clinoform mechanics in the Gulf of Papua, New Guinea: Continental Shelf Research, v. 24, p. 2487-2510. 
WICKENS, H.D.V., 1994, Basin Floor Fan Building Turbidites of the Southwestern Karoo Basin, Permian Ecca Group, South Africa. [unpublished Unpubl. Ph.D. thesis thesis]: University of Port Elizabeth, Port Elizabeth (South Africa), 233 p.

WILD, R., FLINT, S.S., and HOdGSON, D.M., 2009, Stratigraphic evolution of the upper slope and shelf edge in the Karoo Basin, South Africa: Basin Research, v. 21, p. 502-527.

WILD, R., Hodgson, D.M., and FLINT, S.S., 2005, Architecture and stratigraphic evolution of multiple, vertically-stacked slope channel complexes, Tanqua depocentre, Karoo Basin, South Africa, in Hodgson, D.M., and Flint, S.S., eds., Submarine Slope Systems: Processes and Products. Geological Society of London Special Publication 244, p. 89-111.

784

WILSON, R.D., and SCHIEBER, J., 2014, Muddy Prodeltaic Hyperpycnites In the Lower Genesee Group of Central New York, USA: Implications For Mud Transport In Epicontinental Seas: Journal of Sedimentary Research, v. 84, p. 866-874.

Zavala, C., Arcuri, M., and Blanco Valiente, L., 2012, The importance of plant remains as a 788 diagnostic criteria for the recognition of ancient hyperpycnites: Revue de Paléobiologie, Genéve, v. 11, p. 457-469.

Zavala, C., Arcuri, M., Gamero, H., and Contreras, C., 2007, The composite bed: A new distinctive feature of Hyperpycnal deposition., Annual AAPG Convention, April 2-5, 2007: Long Beach, California.

Zavala, C., Gamero, H., and Arcuri, M., 2006a, Lofting rhythmites: A diagnostic feature for the 795 recognition of hyperpycnal deposits, Topical session T136: River Generated Hyperpycnal

Zavala, C., Ponce, J., Arcuri, M., Drittanti, D., Freije, H., and Asensio, M., 2006b, Ancient 798 Lacustrine hyperpycnites: a depositional model from a case study in the Rayoso Formation (Cretaceous) of west-central Argentina: Journal of Sedimentary Research, v. 76, p. 40-58.

800

801

802 
804

805 Figure 1: Cartoon showing nomenclature and main characteristics of shelf-edge versus shelf-confined 806 clinothems. Based on Johannessen and Steel (2005); Helland-Hansen and Hampson (2009);

807 Mountain et al. (2010); Jones et al. (2013).

808

809 Figure 2: Map and general stratigraphy of the SW Karoo Basin showing the Waterford Formation 810 outcrop belt and the location of sedimentary logs and correlation panels in the Tanqua and 811 Laingsburg depocenters. Note that the stratigraphic intervals studied in the two depocenters are not correlated. Stratigraphy modified from Flint et al. (2011).

813

814 Figure 3: Correlation panel of the basin margin succession in the Tanqua depocenter, showing the 815 clinoform stacking of the lower Waterford Formation. Correlation displays thirteen parasequences 816 (C1-13), with their flooding surfaces and main sequence stratigraphic boundaries, as well as the 817 interpreted position of shelf edge rollovers, based on major gradient changes combined with secondary criteria including outcrop-scale growth faults, widespread erosion (gullies) and increase in

819 sandstone turbidites beyond the shelf edge (Jones et al. 2013). A regional mudstone unit on top of 820 Unit 5 acts as a correlation datum. Modified from Wild et al. (2009).

821

822 Figure 4: Correlation panel of the lower Waterford Formation in the Laingsburg depocenter. The 823 Baviaans South (BS), Baviaans North (BN) and Zoutkloof (Z) correlation panels encompass eight lower Waterford parasequences (WfC 1-8). Sequence boundaries, flooding surfaces and a type 2

825 sequence boundary between WfC 5 and WfC 6 are shown. The panels use top of Unit F as a correlation datum. Modified from Jones et al. (2015). Same color code as in Figure 3.

828 Figure 5: Paleogeographic map reconstructions of WfC $6(A)$ and WfC 7 (B) from the data shown in 829 the correlation panels of Fig. 4. (C) Map view of the evolution of the shelf-edge rollover position 830 through time in the Laingsburg depocenter. Note that during WfC 6 and WfC 7 the position of the 831 sand pinchout is not coincident with the interpreted location of the shelf edge rollover. 
833 Figure 6: Representative sedimentary log from the Faberskraal farm locality (Z10, see location in

834 Figure 4A), showing a lower fining-upward unit with bioturbated and nodular siltstones included in the

835 TST associated with WfC 5, followed by an overall coarsening and thickening-up succession (WfC 6-

836 7) of non- to moderately-bioturbated shoreface-offshore transition (SOT) thin beds passing into thicker

837 lower shoreface deposits. Same color code used in Figure 3.

838

839 Figure 7: Detailed view of the correlation along the Zoutkloof area, showing progradation during WfC

840 6-7 after the regional transgression above WfC 5. The absence of delta front/shoreface deposits

841 beyond the WfC 5 shelf-edge rollover position in WfC 6-7 suggests their sand-rich components are

842 shelf-confined deltas (as their sand pinch-out position indicates), with mud-dominated shelf-edge

843 rollovers. Note the low net progradation of the shelf-edge between WfC 4-5 compared with the

844 basinward shift of the sand-rich deformed facies of WfC 8 over $50 \mathrm{~m}$ of mudstones of WfC 6-7 and

845 about $15 \mathrm{~km}$ beyond the pre-established sand-dominated shelf-edge rollover of WfC 5.

846

847 Figure 8: General stratigraphic section of the SL1 research borehole, in the Tanqua depocenter, with 848 detailed sketches/photographs of key mudstone beds (1-6) along C6 and C7. Note the vertical scale 849 of the logs is in centimeters. Cycles in the well log are based on the recognition of flooding surfaces in 850 the core (Wild et al. 2009). VSH = Shale volume from Gamma Ray log.

851

852 Figure 9: Enlarged view of a polished outcrop sample of a typical bi-partite (Type B) thin bed. Note the 853 internal complexity of mud-rich thin beds and the difficulty to recognize their subdivisions in outcrop 854 due to their small-scale expression.

855

856 Figure 10: Cartoon showing the interpreted spatial distribution of dilute gravity flow processes and 857 deposits across a fine-grained shelf-edge rollover associated with storm-dominated shelves. The 858 position of the defined bed types along the depositional profile is extrapolated from their stratigraphic 859 distribution.

860

861 Figure 11: Sketch of shelf-edge rollover areas based in the Waterford Formation stacked basin 862 margin clinothems, with temporal flooded shelf conditions, showing the complexity in rollover 
863 identification and potential risks of clinoform trajectory analysis based on identification of sand-rich 864 rollovers.

865

866 Tables

867 Table 1. Summary of sedimentary facies and facies associations found from the shelf to upper slope 868 of the lower Waterford Fm. based on previous works (Wild et al. 2009; Oliveira et al. 2011; Jones et 869 al. 2013; 2015)

870

871 Table 2. Clinoform thickness and slope variability in the Tanqua and Laingsburg depocenters.

872 Estimated gradients and trajectories are from compacted thickness measurements (see also Wild et 873 al. 2009).

874 
Fig. 1 


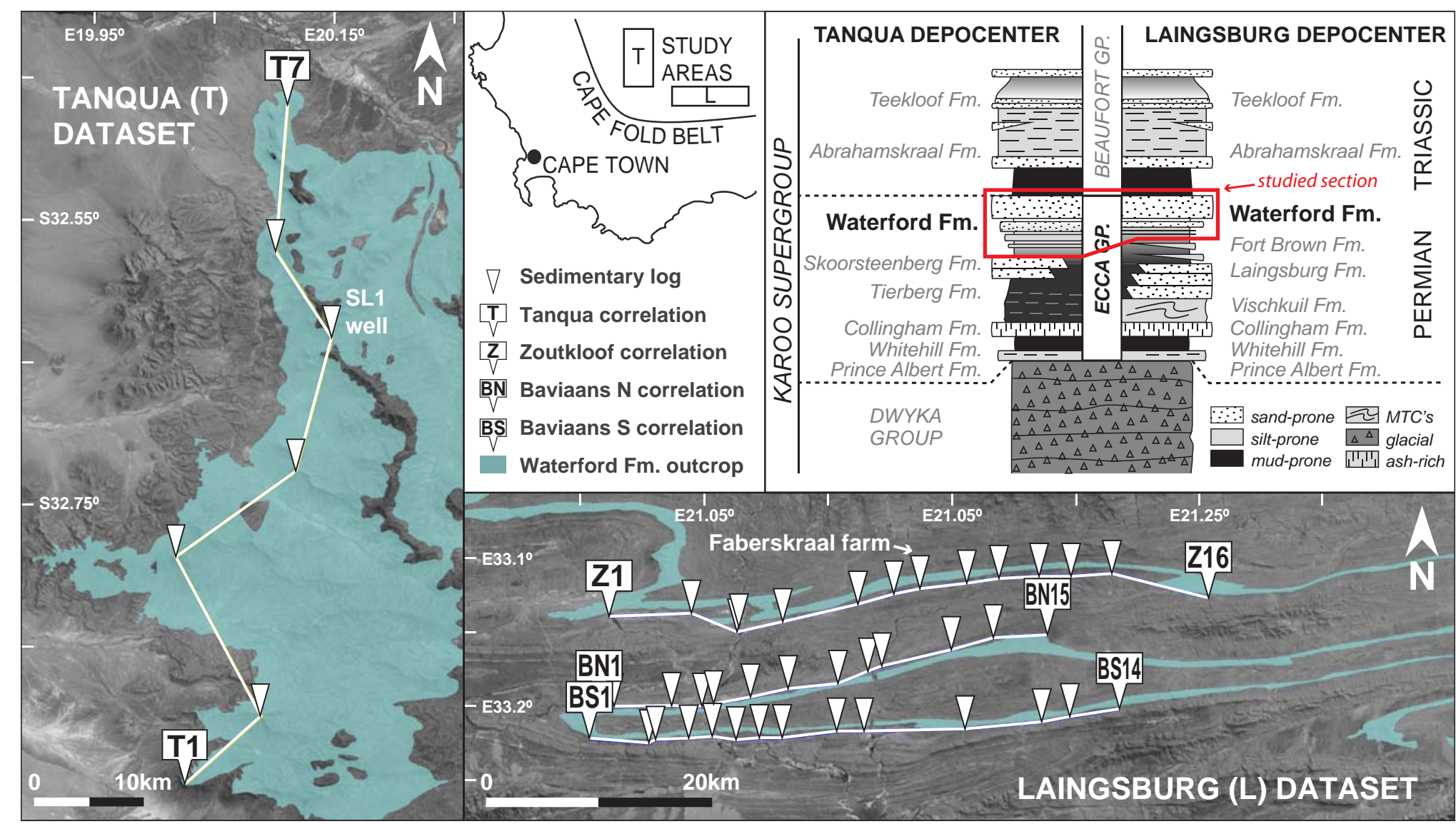

Fig. 2 


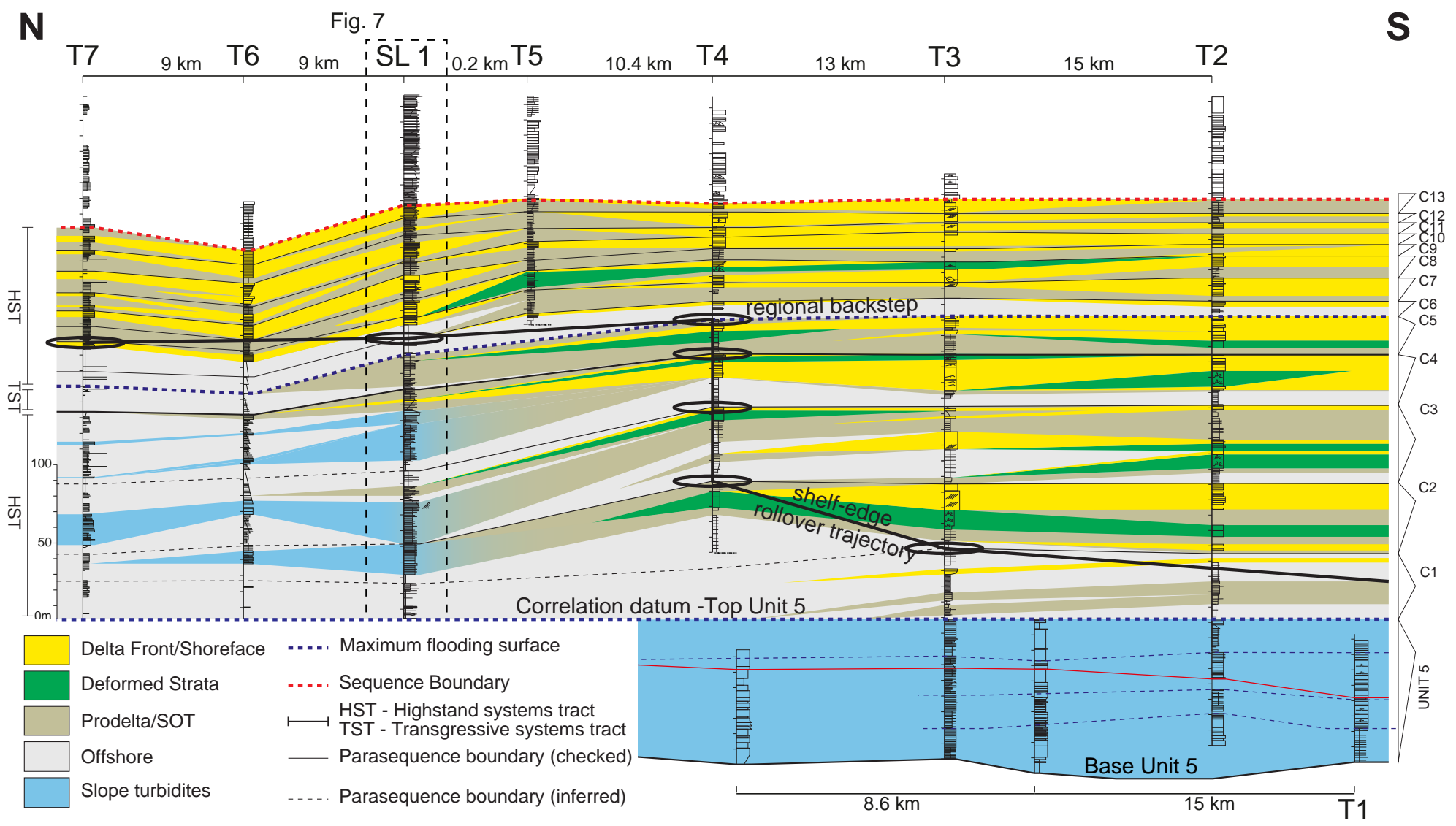

Fig. 3 

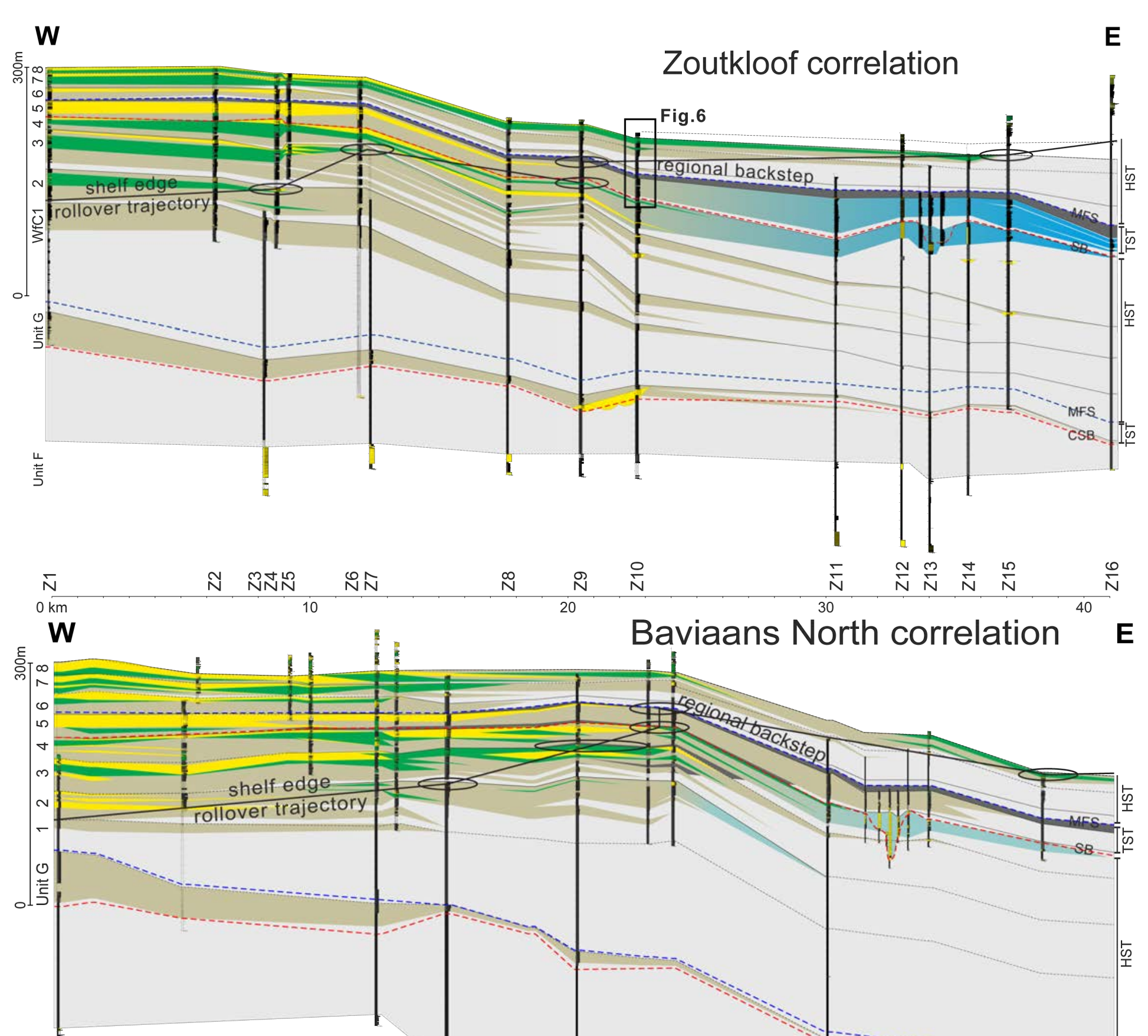

訔

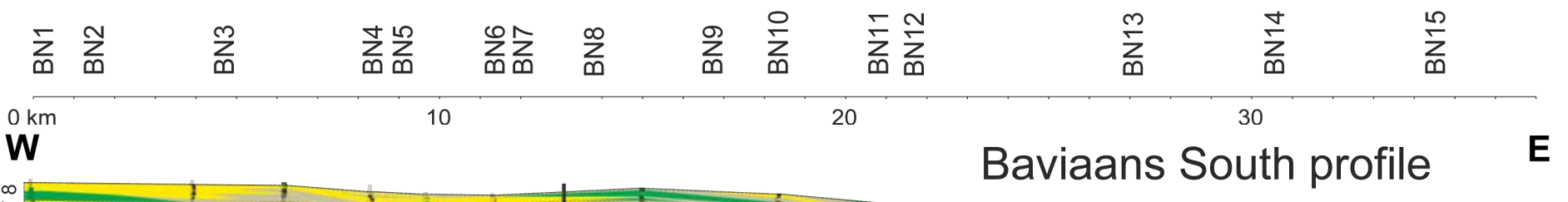
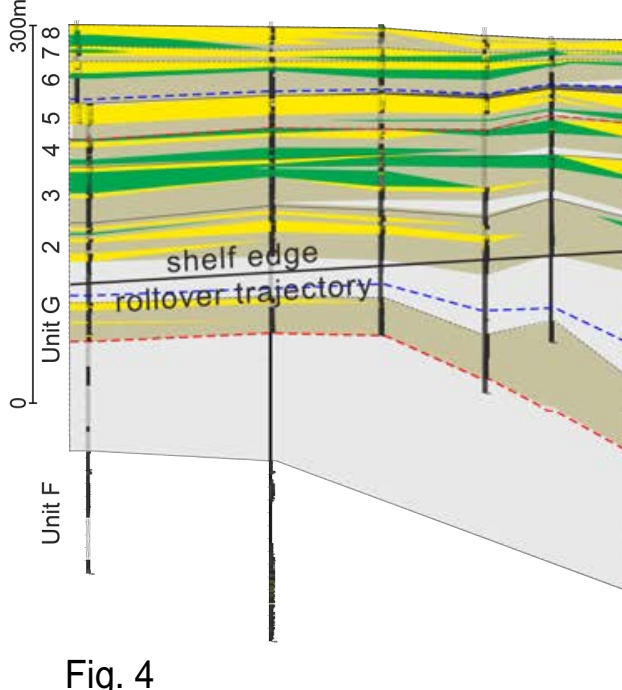

g

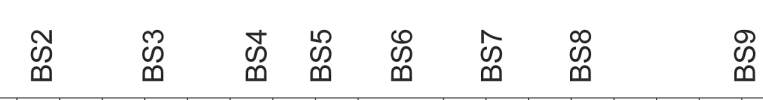

옳

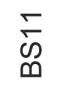



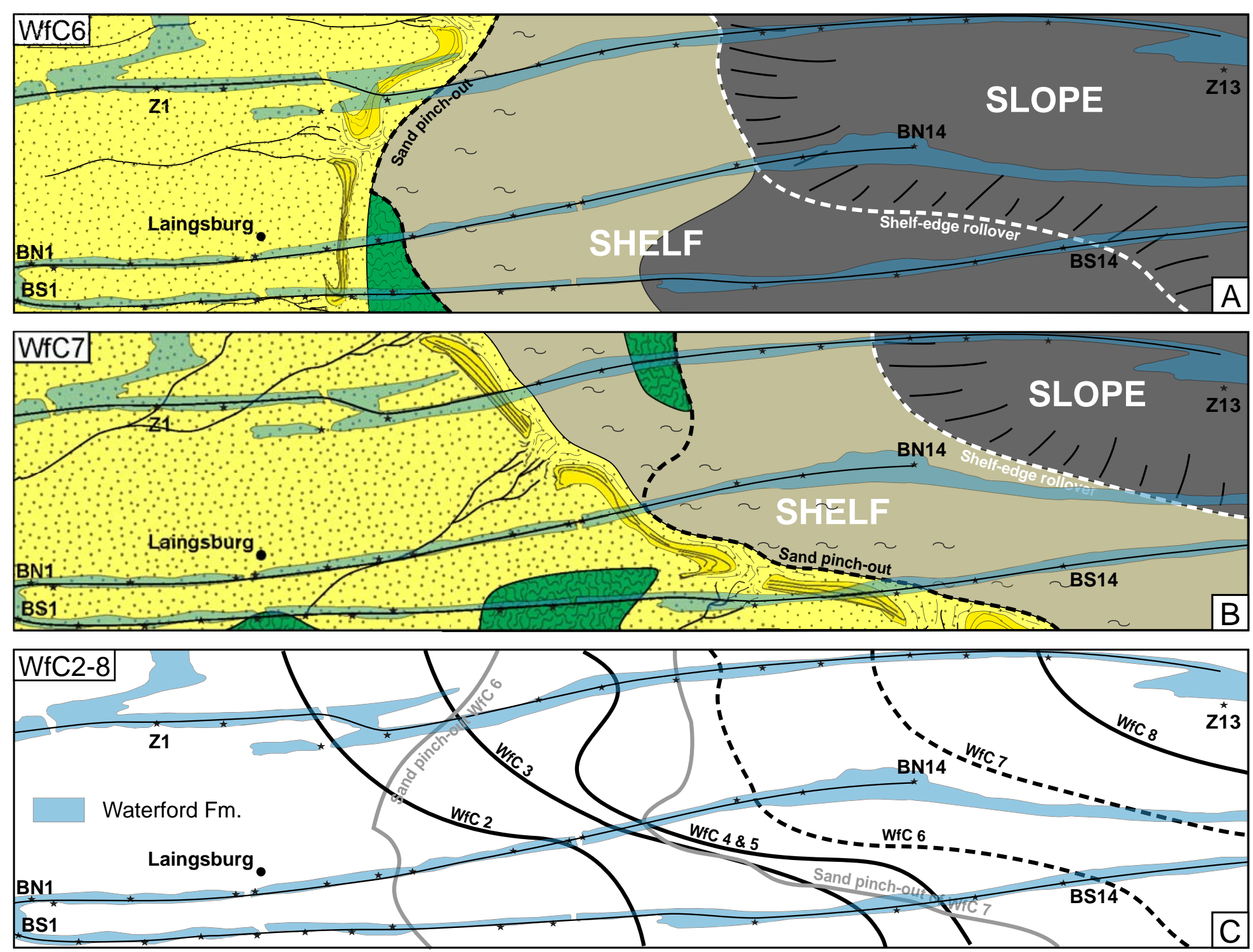

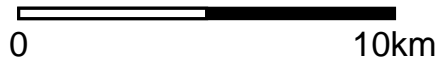

$\therefore \because$ Delta front/shoreface sandstones

$\star$ Correlated sedimentary logs
Deformed sandstones

I Prodelta/SOT transition thin beds

$\square$ Offshore/slope mudstones

Fig. 5 

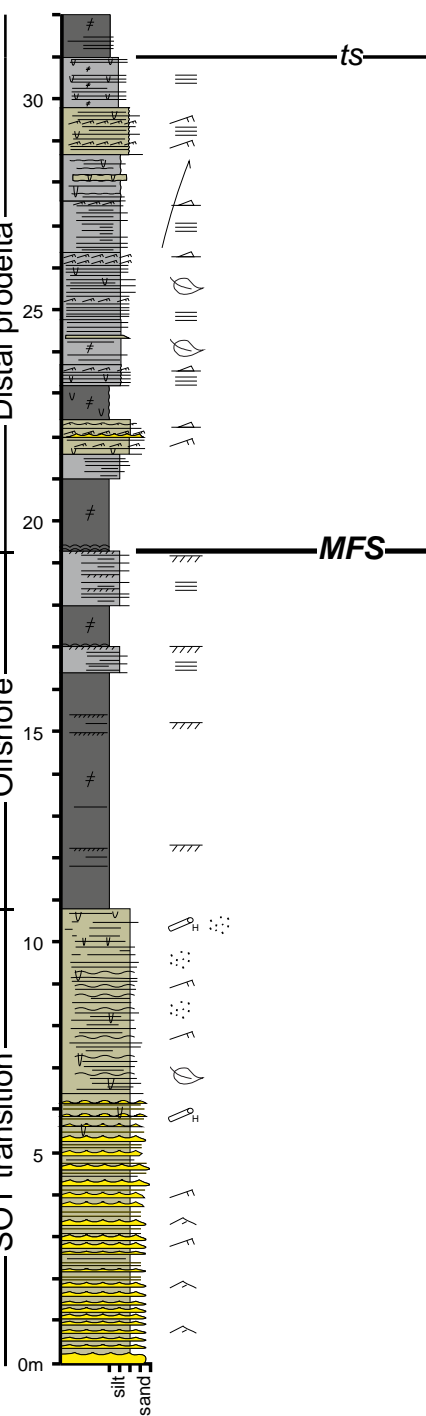

Fig. 6

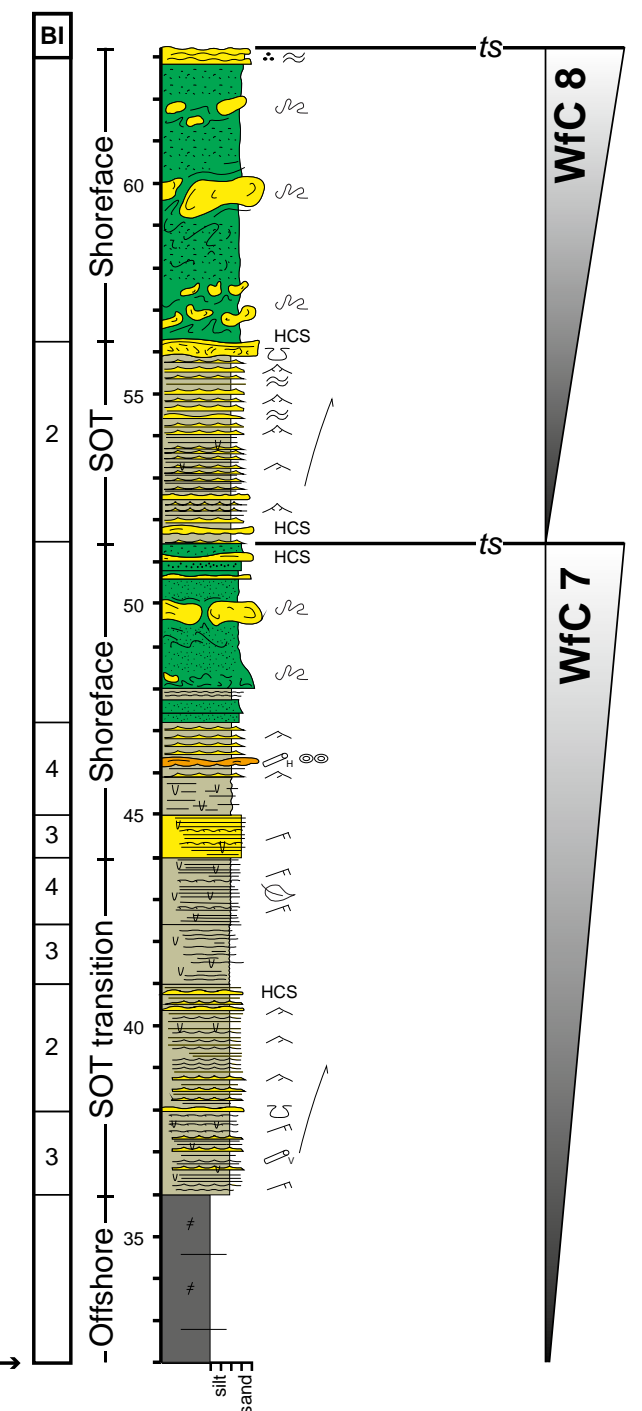

Legend

Symbols

(0) Concretionary level

$\because \quad$ Mottled texture

$\therefore \quad$ Mud clasts

$\ominus$ Plant debris

ת Remobilized sediment

乙 Load casts

HCS Hummocky cross-strat.

A Starved ripples

^ Wave ripples

入 Symmetric current ripples

$\uparrow \quad$ Current ripples

$\approx$ Wavy lamination

$\equiv \quad$ Parallel lamination

$\neq \quad$ Structureless

गाr Iron-rich level

$\varnothing_{\mathrm{H}}$ Horizontal burrowing

Q Vertical burrowing

$\checkmark \cup$ Bioturbation 


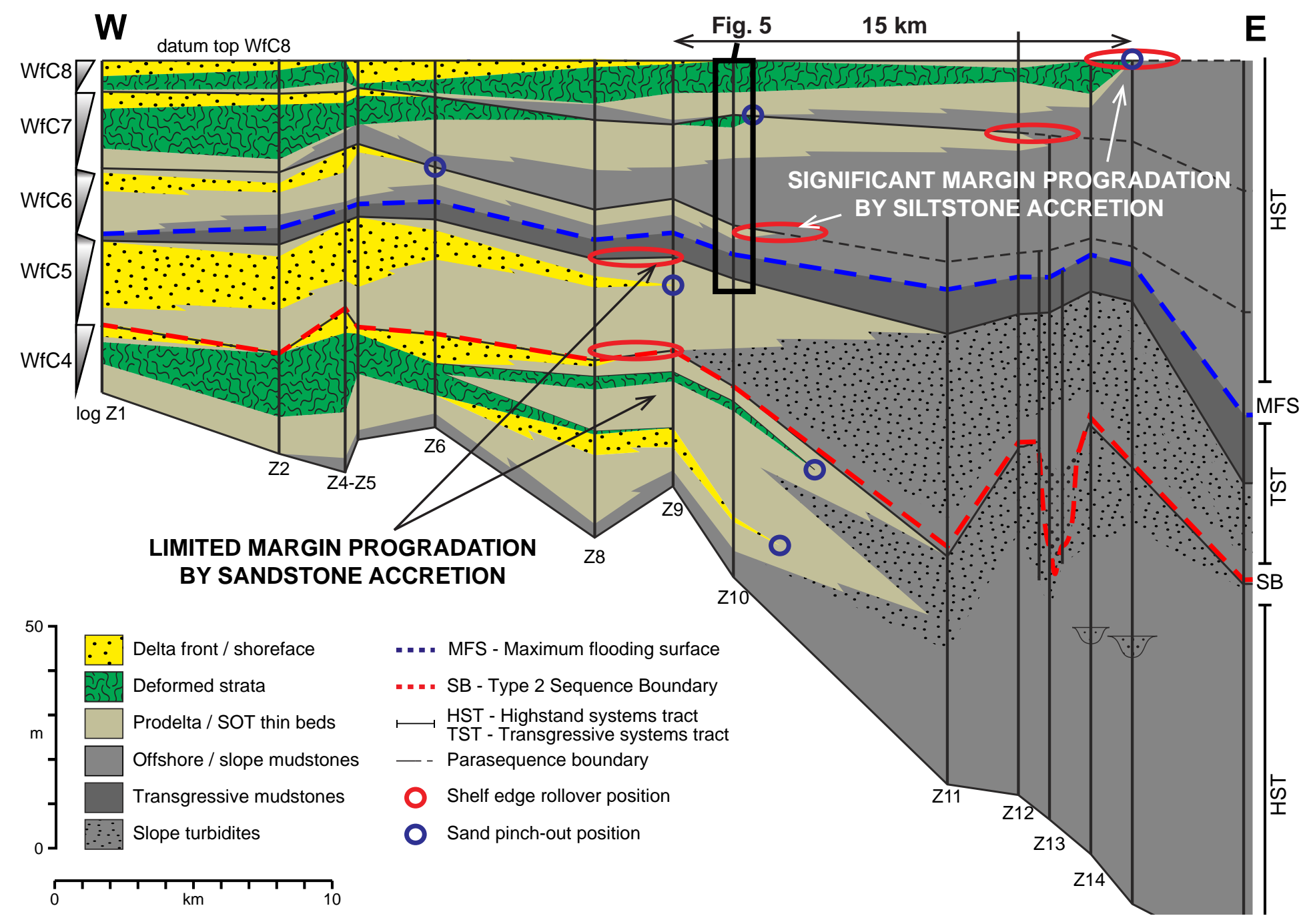

Fig. 7 


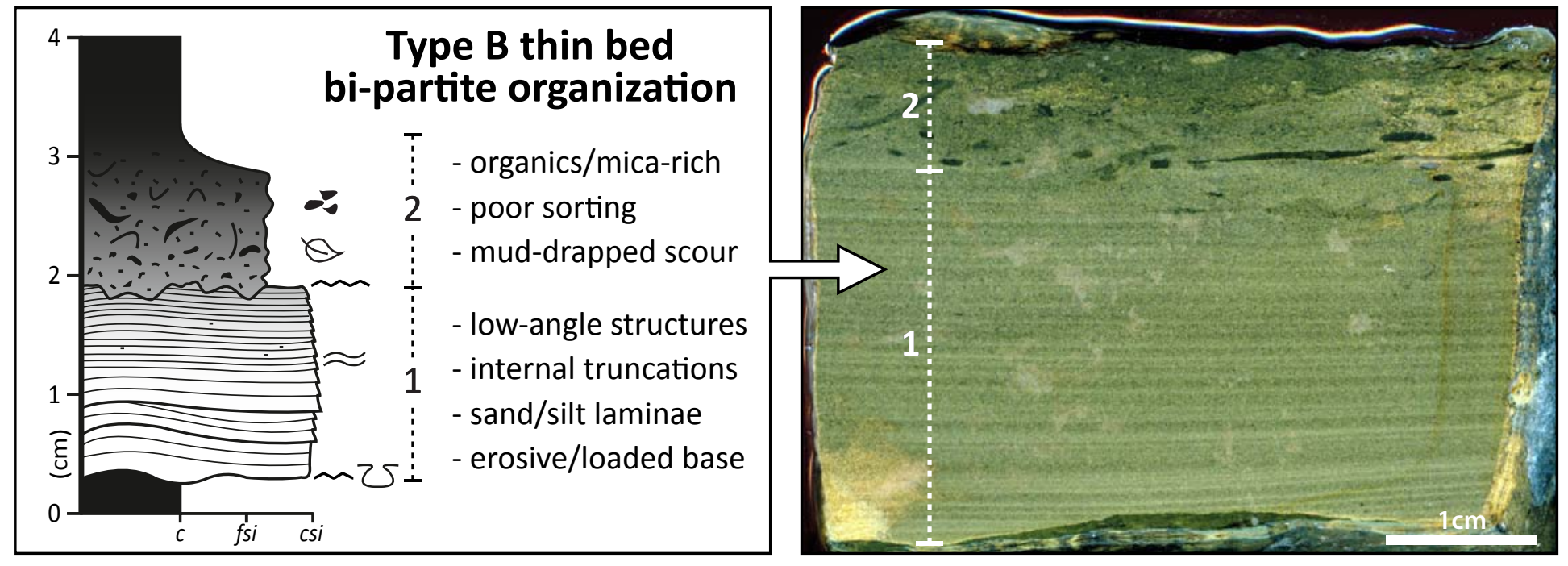

Fig. 9 


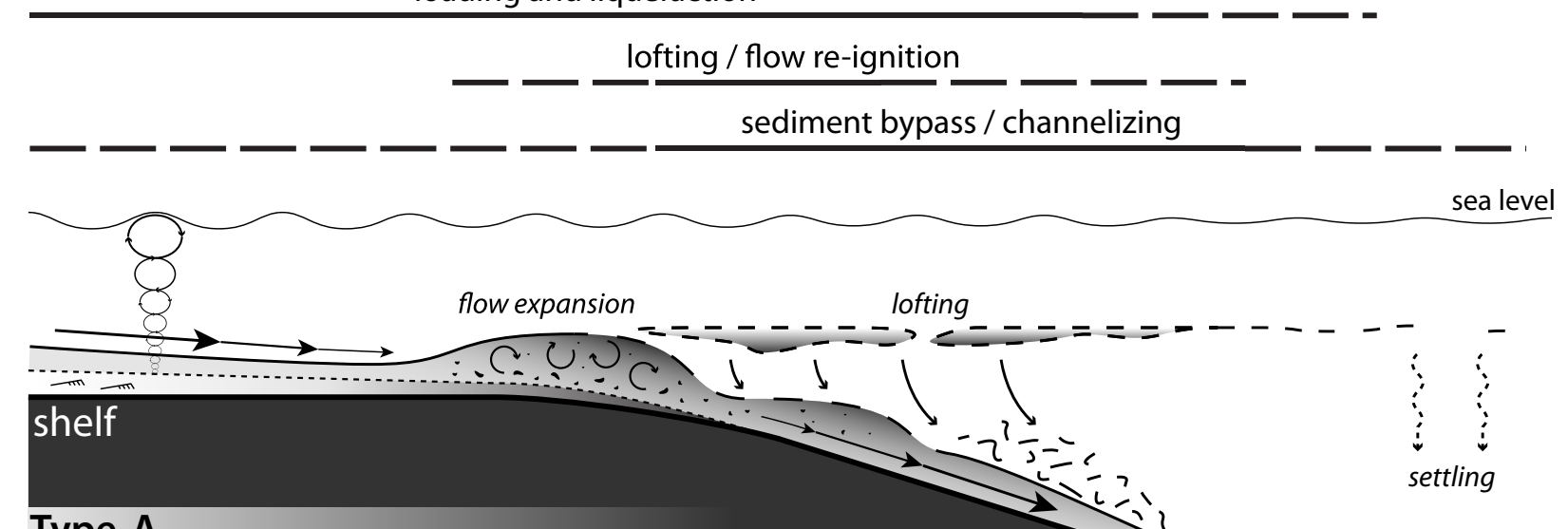

\section{Type-A}

\section{Type-B}

\section{Type-C}

relative frequency of beds

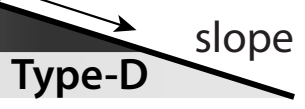

not to scale

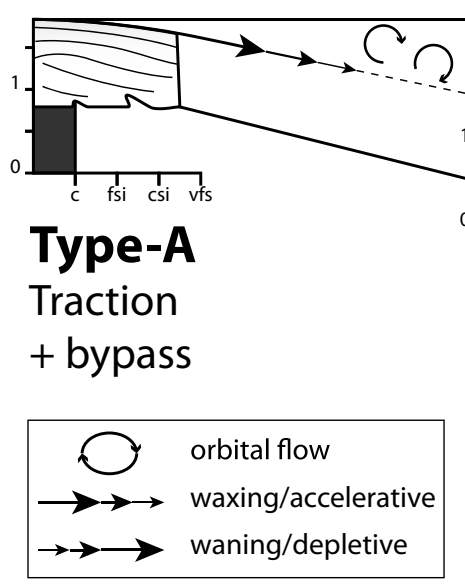

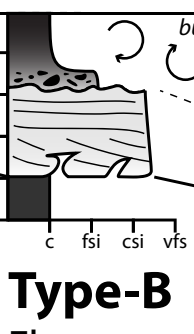

Flow transformation + erosion

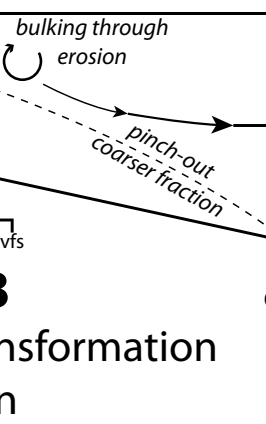

${ }_{0}$

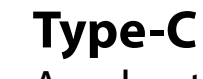

Acceleration

+ bypass
Type-D

Depletion

+ fallout

Fig. 10 


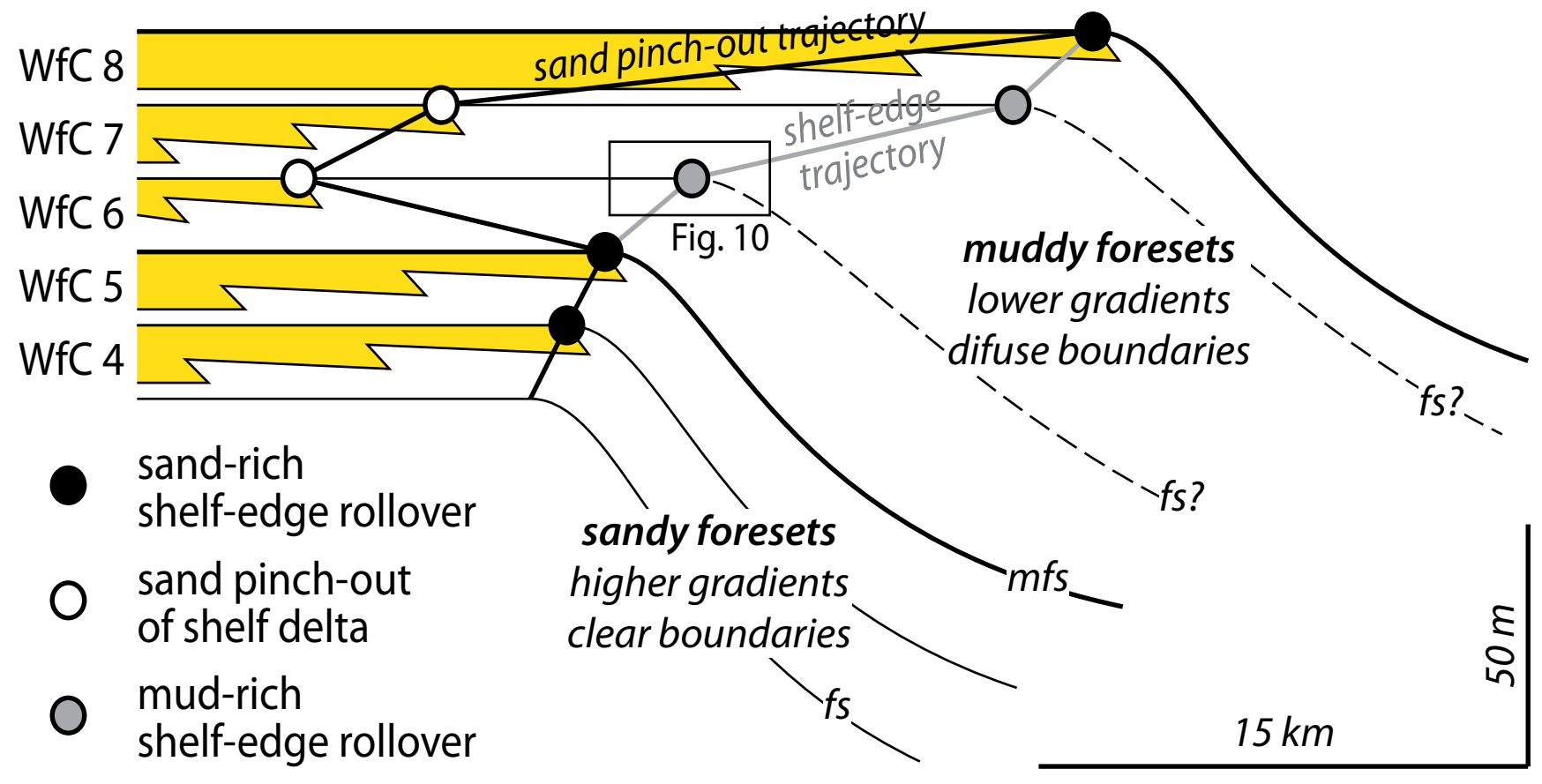

Fig. 11 


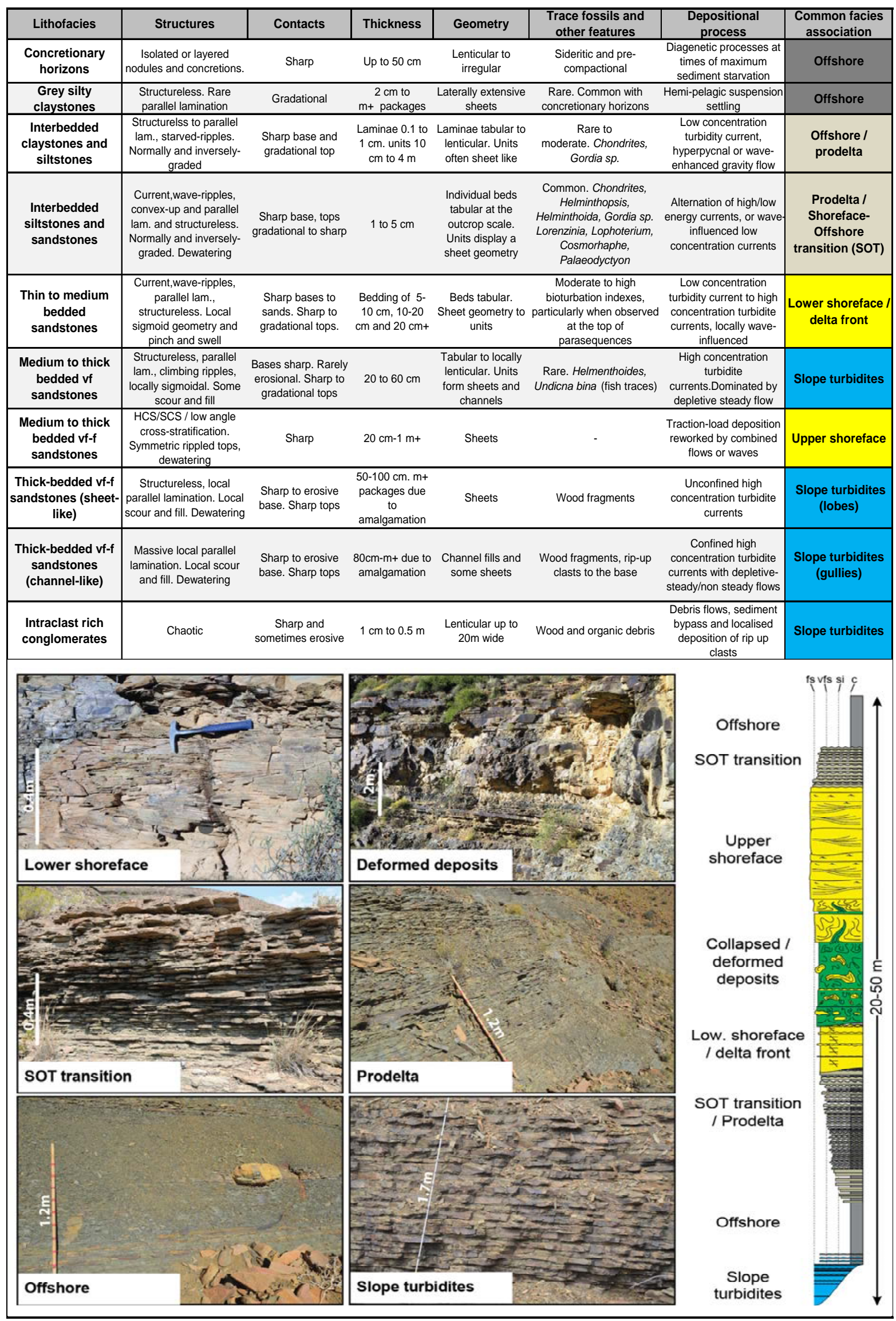

Table 1 


\begin{tabular}{|c|cc|c|c|c|c|}
\hline \multicolumn{7}{|c|}{ LAINGSBURG CLINOFORMS } \\
\hline Cycle & \multicolumn{2}{|c|}{ Thickness (m) } & Gradient (deg) & $\begin{array}{c}\text { Slope } \\
\text { deposits }\end{array}$ & $\begin{array}{c}\text { Rollover } \\
\text { trajectory }\end{array}$ & $\begin{array}{c}\text { Dominant } \\
\text { process }\end{array}$ \\
\hline WfC1 & 163.4 & 23.6 & 0.712 & muddy & flat & river \\
\hline WfC2 & 145.5 & 31.2 & 0.713 & sandy & flat-rising & wave \\
\hline WfC3 & 92 & 34 & 0.700 & mud>sand & flat-rising & river/wave \\
\hline WfC4 & 124 & 16.4 & 0.570 & sandy & rising & wave \\
\hline WfC5 & 58 & 10 & 0.531 & sandy & rising & wave \\
\hline WfC6 & 37 & 6.8 & 0.552 & muddy & flat-falling & river \\
\hline WfC7 & 38 & 7 & 0.531 & muddy & flat-falling & river \\
\hline WfC8 & 23 & 6.04 & 0.513 & sandy? & falling & river \\
\hline
\end{tabular}

\begin{tabular}{|c|cc|c|c|c|c|}
\hline \multicolumn{7}{|c|}{ TANQUA CLINOFORMS } \\
\hline Cycle & \multicolumn{2}{|c|}{ Thickness (m) } & Gradient (deg) & $\begin{array}{c}\text { Slope } \\
\text { deposits }\end{array}$ & $\begin{array}{c}\text { Rollover } \\
\text { trajectory }\end{array}$ & $\begin{array}{c}\text { Dominant } \\
\text { process }\end{array}$ \\
\hline C1 & 45 & 21 & 0.435 & muddy & flat & river \\
\hline C2 & 52 & 17 & 0.512 & sandy & flat-rising & river/wave \\
\hline C3 & 44 & 31 & 0.504 & sand>mud & rising & river/wave \\
\hline C4 & 54 & 32 & 0.439 & mud>sand & rising & river \\
\hline C5 & 32 & 13 & 0.455 & mud>sand & rising & river/tide \\
\hline C6 & 15 & 10 & 0.455 & muddy & flat-falling & river \\
\hline C7 & 19 & 9.5 & 0.458 & muddy & flat-falling & river \\
\hline C8 & 14 & 7 & 0.474 & sand>mud & flat-rising & river \\
\hline
\end{tabular}

Table 2 